\title{
Mono- and dicyrtid Nassellaria (Radiolaria) from the Upper Carnian of the Sorgun Ophiolitic Mélange, Southern Turkey and Kopría Mélange, Rhodes, Greece
}

\author{
Radiolaires nassellaires mono- et dicyrtides du Carnien supérieur du Mélange Ophiolitique de \\ Sorgun, Turquie Méridionale et du Mélange de Kopría, Rhodes, Grèce \\ Péter Ozsvárt $^{\mathrm{a}, *}$, Paulian Dumitrica ${ }^{\mathrm{b}}$, Alexandre Hungerbühler ${ }^{\mathrm{b}}$, Patrice Moix ${ }^{\mathrm{c}}$ \\ ${ }^{\text {a } M T A-M T M-E L T E, ~ R e s e a r c h ~ G r o u p ~ f o r ~ P a l e o n t o l o g y, ~ P . O . ~ B o x ~ 137, ~} 1431$ Budapest, Hungary \\ ${ }^{\mathrm{b}}$ Institute of Earth Sciences, Université de Lausanne, Géopolis, 1015 Lausanne, Switzerland \\ ${ }^{\mathrm{c}}$ Rue de la Combe 55, 1969 Eison, Switzerland
}

\begin{abstract}
Four new genera (Circopoulpus nov. gen., Aropeon nov. gen., Tekinium nov. gen., Caponabolella nov. gen.) and 19 new characteristic monoand dicyrtid Nassellarian species are described herein from two of the most diverse and best preserved Carnian (Late Triassic) radiolarian faunas of the world, which are the lower Tuvalian sequence of the Sorgun Ophiolitic Mélange, southern Turkey, and the Kopría Mélange, Rhodes, Greece. (C) 2016 Elsevier Masson SAS. All rights reserved.
\end{abstract}

Keywords: Radiolaria; Nassellaria; Carnian; Sorgun Ophiolitic Mélange; Kopría Mélange; New Taxa

\section{Résumé}

Quatre nouveaux genres (Circopoulpus nov. gen., Aropeon nov. gen., Tekinium nov. gen., Caponabolella nov. gen.) et 19 nouvelles espèces de Nasselaires mono- et dicyrtides sont décrits à partir de matériel provenant de deux des plus diverses et mieux préservées faunes de radiolaires du monde d'âge Tuvalien inférieur (Carnien, Trias supérieur). Les faunes proviennent du Mélange ophiolitique de Sorgun, Turquie méridionale, et du Mélange de Kopría, Rhodes, Grèce.

(C) 2016 Elsevier Masson SAS. Tous droits réservés.

Mots clés : Radiolaires ; Nassellaires ; Carnien ; Mélange ophiolitique de Sorgun ; Mélange de Kopría ; Nouveaux Taxons

\section{Introduction}

The Carnian was one of the most important intervals in the evolution of Triassic radiolarian faunas (O'Dogherty et al., 2010) at generic and family levels (De Wever et al., 2003). Radiolarian genera reached their highest diversity (Fig. 1) during the Julian and early Tuvalian, after the decrease of the number of new taxa around the Ladinian-Carnian boundary (Fig. 1). This

\footnotetext{
* Corresponding author.

E-mail address: ozsi@nhmus.hu (P. Ozsvárt).
}

period was particularly important especially for spumellarians and entactinarians, when started the diversification of special groups bearing tumidaspinae (families Capnuchosphaeridae De Wever, Eptingiidae Dumitrica) or saturnalid ring (Saturnalidae Deflandre, Spongosaturnalidae Kozur \& Mostler), whose first appearance took place in fact during the Longobardian. The causes and consequences of these unique evolutionary innovations and accelerated rates of evolutionary changes in Carnian radiolarians are still unclear. Fortunately, perfectly preserved Carnian radiolarian faunas are known from different localities (e.g. Lagonegro Basin, Italy; Sosio Valley, Sicily; Göstling and Großreifling, Northern Calcareous Alps, Austria; Nosztor 


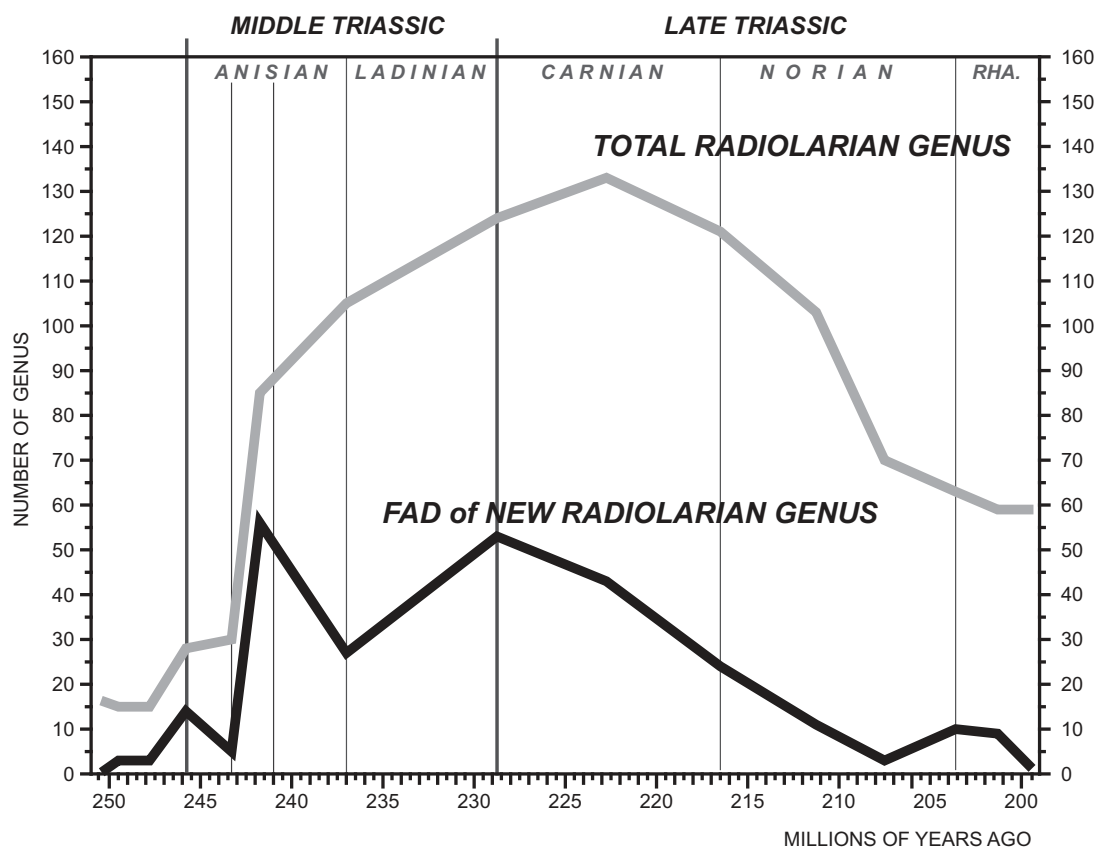

Fig. 1. Radiolarian genus diversity through Triassic after O'Dogherty et al., 2010 (FAD and LAD of some genera were modified in some cases).

Valley, Hungary; Mersin Ophiolitic Complex, and Elbistan, Köseyahya Nappe, Turkey; Zulla Formation, Hawasina Complex, Oman) in the Tethyan realm from the lower Julian to the lower Tuvalian. One such extremely well-preserved and particularly diverse lower Tuvalian (Upper Carnian) radiolarian fauna is known from the Sorgun Ophiolitic Mélange (Mersin Ophiolitic Complex), Turkey, which was discovered near to Sorgun village in 2003 by Masset and Moix. Moix et al. (2007) established the lower Tuvalian Spongotortilispinus moixi radiolarian zone and described several radiolarian species from this zone. Numerous additional radiolarian taxa were subsequently described from the type locality of the $S$. moixi zone in a series of papers by Kozur et al. (Kozur et al., 2007a, b, c; Kozur et al., 2009) and Ozsvárt et al. (2015). Thus far, three new families, 11 new genera, and 113 new species and subspecies have been described. Another lower Tuvalian radiolarian fauna of practically equal composition, preservation, lithology and age has been also found close to the Kritinia village in Kopría Mélange, Rhodes, Greece (Moix et al., 2008b). These similarities prove doubtlessly that both faunas come from the same paleogeographic area. These two faunas have many elements in common with the upper Carnian (Tetraporobrachia haeckeli Zone) fauna from the Köseyahya Nappe in Elbistan (Tekin and Bedi, 2007a, b, Dumitrica et al., 2010, 2013a, b). In this paper, we continue the taxonomic work of the exceptionally preserved lower Tuvalian radiolarians by the description of several new taxa of Nassellaria from the Sorgun Ophiolitic Mélange and from the Kopría Mélange, Rhodes (Greece).

\section{General geology of the ophiolitic mélanges}

The ophiolites and related mélanges in the Eastern Mediterranean region (Fig. 2) provide one of the most important clues for the reconstruction of the geodynamic evolution of the
Paleotethyan and Neotethyan series (e.g. Gawlick et al., 2016). The ophiolites in the Eastern Mediterranean formed in a variety of tectonic settings (Robertson, 2002). The mainly Triassic and Jurassic ophiolites and related oceanic magmatic units are exposed in the Dinarides - Hellenides (Dinaridic Ophiolite belt - Mirdita - Pindos - Vourinos) belt, while the mainly Cretaceous ophiolites and associated units are represented in the Taurides of southern Turkey. Several dismembered ophiolite units and related ophiolitic mélange of this Cretaceous belt appear in the Mersin Ophiolitic Complex, Southern Turkey (Mersin) and on the Rhodes Island, Greece. The Mersin Ophiolitic Complex belongs to the South-Taurides exotic units (Moix et al., 2008a) and exhibits typical oceanic fragments with ophiolitic series, sub-ophiolitic metamorphic sole and associated infra-ophiolitic mélange. The Mersin ophiolite formed in a supra-subduction zone tectonic setting during the Late Cretaceous (Parlak and Delaloye, 1996) and includes two major independent mélange units identified in the Mersin Ophiolitic Complex: the Upper Cretaceous Sorgun Ophiolitic Mélange and the Middle to Upper Triassic Hacialanı Mélange (Moix et al., 2011). One of the most important and well-developed tectonic blocks of the Sorgun Ophiolitic Mélange is the Tavusçayırı Block where the well-preserved and particularly diverse lower Tuvalian radiolarian fauna was found (Masset and Moix, 2004). This tectonic block contains several typical deep-sea sedimentary units of the Huğlu-Pindos series, which are well known from the Hellenides-Taurides belt.

The Upper Cretaceous ophiolites of Rhodes, which represent a displaced fragment of the major Cretaceous ophiolite belt of the Eastern Mediterranean region, were also formed in a supra-subduction zone (Koepke et al., 2002). The associated infra-ophiolitic Kopría Mélange occurs discontinuously and is tectonically sandwiched between the Pindos Zone (Profitis Ilias Zone) and the underlying Gavrovo-Tripolitsa Zone 


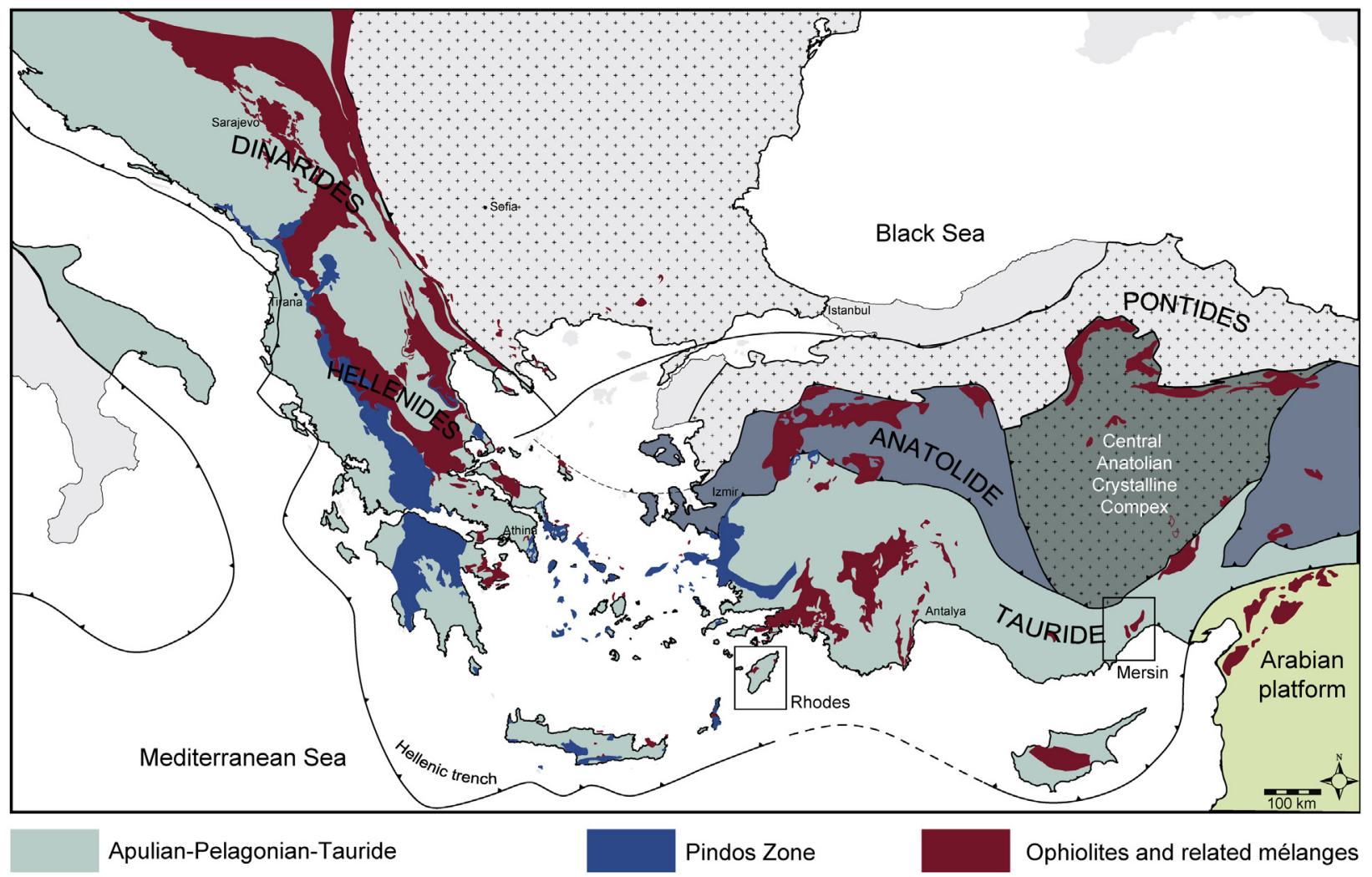

Fig. 2. Schematic tectonic map of Eastern Mediterranean region. Simplified after Moix et al. (2008a) and Schmid et al., unpublished tectonic units of the Alpine collision zone between Eastern Alps and Western Turkey.

(Lindos-Archangelos Group) in an allochthonous series (Lekkas et al., 2002). This radiolarian study provides important clues for the knowledge of the geodynamic evolution of the Tethyan sequences by dating infra-ophiolitic mélange elements.

\subsection{Sorgun Ophiolitic Mélange}

The geological setting of the investigated Tavusçayırı block was discussed in detail by Moix et al. (2007); Moix et al. (2011) and the section was published in several additional papers (Kozur et al., 2007a; Kozur et al., 2009; Ozsvárt et al., 2015). The sequence starts with polymictic breccia and polygenic clastsupported conglomerate in a red micritic and silty matrix, which is mostly composed of neritic limestone blocks. Some elements yielded Middle Triassic pelagic faunas. It is followed by $15 \mathrm{~m}$ of black Middle Triassic (Anisian?) calciturbidites, which contains reworked foraminifers, corals (Permian?), algae and megalodontid-type bivalves. The series continues with a brownish, medium-bedded Upper Triassic (Carnian?) limestone containing typical reefal organisms. This shallow water carbonate is covered by typical Hallstatt Limestone, which yielded an upper Julian ammonoid assemblage of the Austrotrachyceras austriacum Zone, foraminifera, echinoderms, crinoids, fish remains, brachiopods and conodonts of middle Carnian age. In the reference section, the Hallstatt Limestone is conformably overlain by $130 \mathrm{~m}$ of thin-bedded Huğlu-type redeposited green tuffites (Pietra Verde-like tuffs). The tuffitic series is interspersed with alternations of micritic limestone and calciturbidites. One micritic limestone level (Sample G11, see section with sample numbers in Kozur et al., 2007a; Moix et al., 2007; Ozsvárt et al., 2015) contains conodonts, sponge spicules, ostracods and a well-preserved radiolarian fauna of the lower Tuvalian Spongotortilispinus moixi Zone.

\subsection{Kopría Mélange, Rhodes (Greece)}

Rhodes is composed of several thrust sheets (Fig. 3) characterized by continental margin to oceanic series (e.g. Mutti et al., 1970, Koepke et al., 2002). The Profitis Ilias Zone is composed of Upper Triassic flysch type deposits with Aulacoceras sp., marls and Halobia-bearing pelagic limestones, followed by a pelagic Mesozoic sequence underlying a lower to middle Maastrichtian flysch unit. The Kopría Mélange, located between the lower Oligocene Katavia flysch and the Carnian to Cretaceous slope to basin series of the Profitis Ilias Group, represents locally dismembered units of the latter (Fig. 3).

\section{Radiolarian fauna}

\subsection{Age of the radiolarian fauna}

The age of the radiolarian fauna of the Sorgun Ophiolitic Mélange is based on the occurrence of Paragondolella noah (Hayashi) in sample G11 (see section with sample numbers in Kozur et al. (2007a); Moix et al. (2007); Ozsvárt et al. (2015)) and data from several other conodont studies from the underlying 

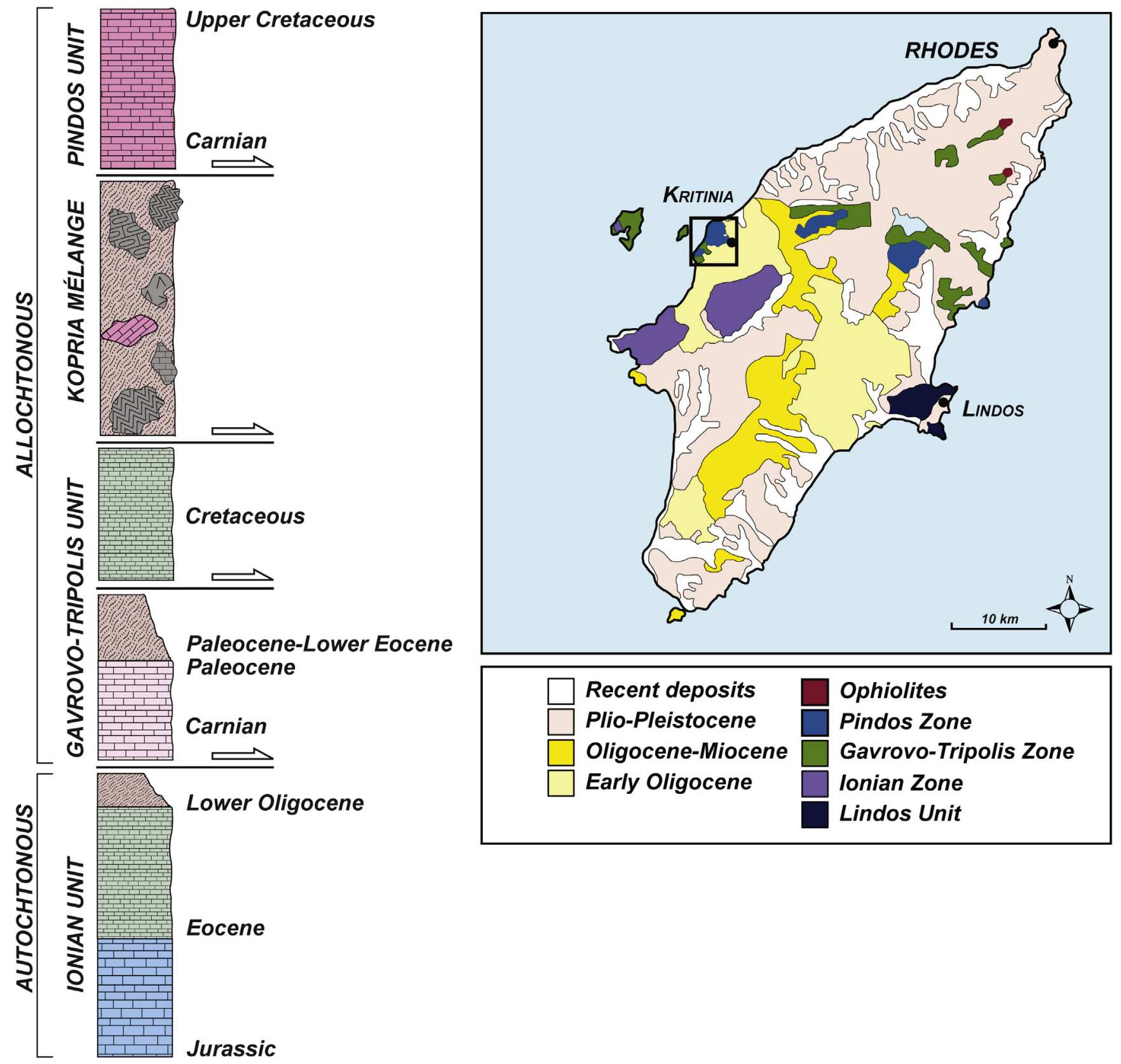

Fig. 3. Simplified geological map and generalized log of tectonic unites of Rhodes, Greece (after Moix et al., 2008b).

Hallstatt Limestone of the section. Sample G7 contains a relatively rich conodont association with Carnepigondolella nodosa (Hayashi) s. s. (=Epigondolella carnica (Krystyn), Gladigondolella tethydis (Huckriede) and Paragondolella noah (Hayashi) indicating an early Julian age. An unpublished ammonite fauna from the underlying Hallstatt Limestone succession confirms the same age (Austrotrachyceras austriacum ammonoid Zone). Sample G 11 contains the best-preserved and most diverse radiolarian fauna of the basal Tuvalian (Spongotortilispinus moixi Zone) in the world (Fig. 4). An equivalent but not so rich radiolarian fauna has been partly described by Dumitrica et al. (2010, 2013a, b) and Dumitrica and Hungerbühler (2007) from cherts of the Zulla Formation, Hawasina Complex, Oman.

\subsection{Radiolarian faunal composition}

As mentioned above, radiolarian fauna from the Sorgun Ophiolitic Mélange (Mersin Ophiolitic Complex) is very well preserved and very diverse. Thus far, 198 different species have been identified, of which 113 have been described as new species and subspecies (Table 1). Spumellarians dominate the fauna (approximately $45 \%$ of the whole fauna belongs to spumellarians), although the diversity of nassellarians and entactinarians is also extremely high $(\sim 35 \%$ of taxa belongs to nassellarians and $\sim 20 \%$ belongs to the entactinarians, although these values may change after subsequent studies). The radiolarian fauna from the Kopría Mélange, Rhodes, Greece (Moix et al., 2008b), is very 


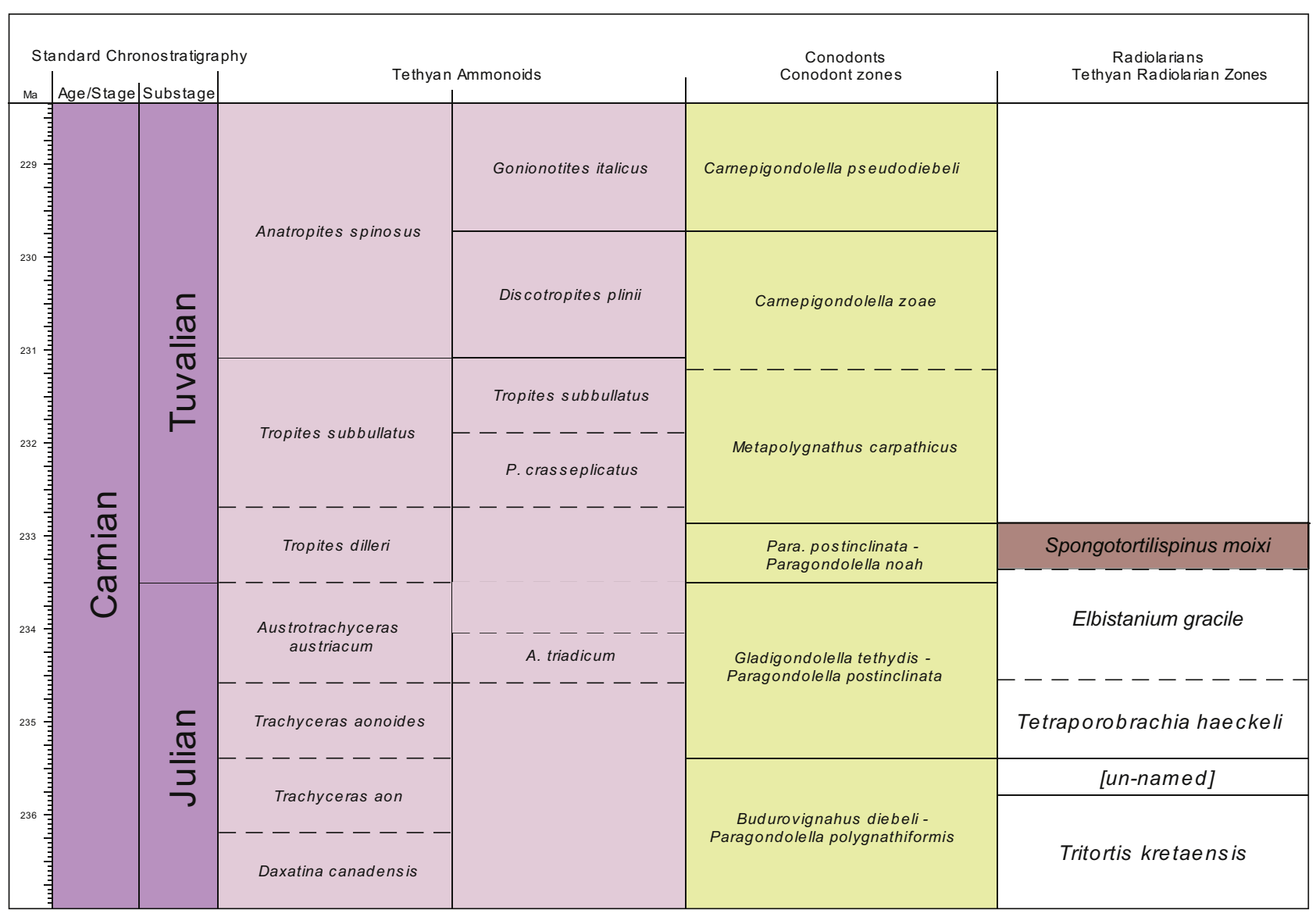

Fig. 4. Ammonite, Conodonts and Radiolarian zonation for the Carnian.

similar to the radiolarian fauna of Sorgun Ophiolitic Mélange in both diversity and preservation, the difference between them being insignificant.

\section{Systematic paleontology}

The holotypes and paratypes from the Sorgun Ophiolitic Mélange has been deposited in the Hungarian Natural History Museum in Budapest, Hungary (HNHM) and those from the Kopría Mélange in the Musée Géologique de Lausanne (MGL). The authors of the new taxa are Ozsvárt, Dumitrica \& Hungerbuhler.

Class Radiolaria Müller, 1858

Subclass Polycystina Ehrenberg 1838 emend. Riedel, 1967

Order Nassellaria Ehrenberg, 1875

Family Poulpidae De Wever, 1981

Genus Poulpus De Wever, 1979

Type species: Poulpus piabyx De Wever, 1979

\section{Poulpus compactus Ozsvárt, Dumitrica \& Hungerbuhler nov.} sp.

Plate 1, figs. 1-2

Description: Test hemispherical with three strong curved feet. Cephalis slightly compressed with polygonal pore frames and without apical horn. On its cupola the three cephalic arches (AV and $2 \mathrm{Al}$ ) are well marked by ridges. Base of cephalis with a circumferential ridge below which a thin, fragile, tubular thorax may be developed; thorax wears many, tiny polygonal pores and its distal end is ragged. Feet are strongly inwardly bent with a large, oval pore at the proximal part, and are distally pointed; they are T-shaped in cross-section with flat or convex outer surface and wide lateral ridges.

Material: More than 10 specimens.

Holotype: The specimen in Pl. 1, fig. 2, HNHM, PAL 2016.17.1.

Dimensions (in $\mu \mathrm{m}$ based on 2 specimens): Height of cephalis 69-83, diameter of cephalis 83-111, length of feet 222-277.

Remarks: Although the presence of the apertural circumferential ridge would suggest that this species should belong to the genus Veghia Kozur and Mostler, 1981, this species, as well as the following two ones, has more characters suggesting that they are closer to Poulpus, such as the presence of a large cephalic pore at the base of feet and the position of the feet blades. With Veghia and its synonym, Triarcopoulpus Kozur, Moix and Ozsvárt, 2007, the feet have one blade external and two lateral, and no pore at the base of feet. Poulpus elegans nov. sp. differs from $P$. compactus nov. sp. by lacking the proximal pore on feet and by significantly different (angular) shaped feet. $P$. compactus nov. sp. differs from P. oertlii (Kozur and Mostler, 1979) by the presence of a large cephalic pore at the base of feet 
Table 1

Occurrence chart of the radilarian taxa from the Sorgun Ophiolitic Mélange, Turkey and from the Kopría Mélange, Rhodes, Greece.

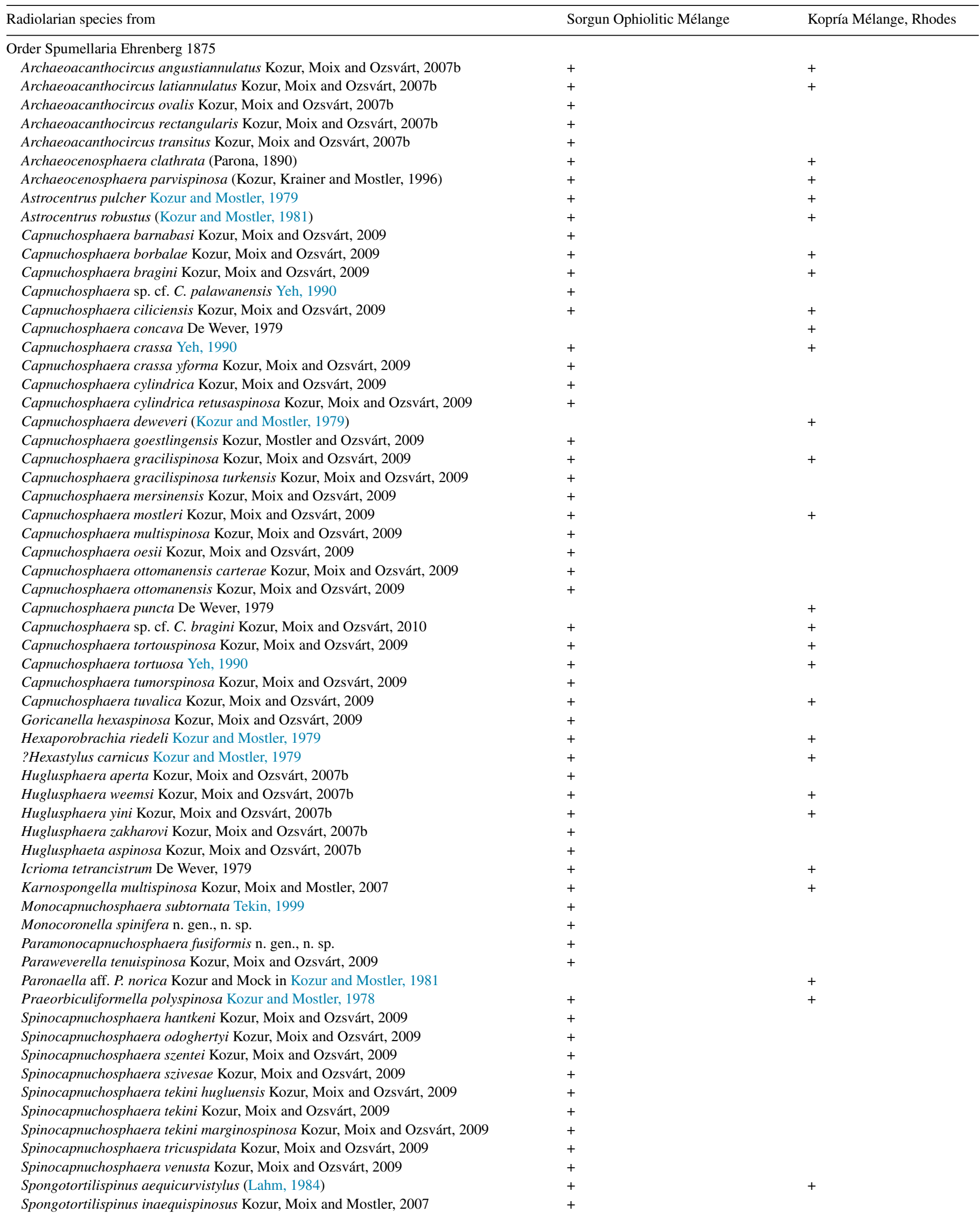

Please cite this article in press as: Ozsvárt, P., et al., Mono- and dicyrtid Nassellaria (Radiolaria) from the Upper Carnian of the Sorgun Ophiolitic Mélange, Southern Turkey and Kopría Mélange, Rhodes, Greece. Revue de micropaléontologie (2016), http://dx.doi.org/10.1016/j.revmic.2016.11.004 
Table 1 (Continued)

\begin{tabular}{|c|c|c|}
\hline Radiolarian species from & Sorgun Ophiolitic Mélange & Kopría Mélange, Rhodes \\
\hline Spongotortilispinus moixi Kozur and Mostler, 2007 & + & + \\
\hline Spongotortilispinus ozsvarti Kozur, Moix and Mostler, 2007 & + & + \\
\hline Spongotortilispinus tortilis Moix and Mostler, 2006 & + & + \\
\hline Spongotortilispinus turkensis Kozur, Moix and Mostler, 2007 & + & + \\
\hline Spongotortilispinus tuvalicus Moix and Mostler, 2007 & + & \\
\hline Tamonella aspinosa $\mathrm{n} . \mathrm{sp}$ & + & \\
\hline Tamonella multispinosa Dumitrica, Kozur and Mostler, 1980 & + & \\
\hline Tetracapnuchosphaera? voeroesi Kozur, Moix and Ozsvárt, 2009 & + & \\
\hline Triassobullasphaera hemisphaerica Kozur and Mostler, 2006 & + & + \\
\hline Triassobullasphaera miriae Ozsvárt, Moix and Kozur, 2015 & + & \\
\hline Triassocrucella baloghi (Kozur and Mostler, 1978) & + & + \\
\hline Tubospongopallium inaequispinosum Kozur, Moix and Ozsvárt, 2009 & + & + \\
\hline Weverella gracilispinosa Kozur, Moix and Ozsvárt, 2009 & + & \\
\hline Weverella longispinosa curvata Kozur, Moix and Ozsvárt, 2009 & + & \\
\hline Weverella longispinosa Kozur, Moix and Ozsvárt, 2009 & + & + \\
\hline Weverella longispinosa subrectangularis Kozur, Moix and Ozsvárt, 2009 & + & \\
\hline Weverella tetrabrachiata Kozur and Mostler, 1979 & + & + \\
\hline Zhamojdasphaera latispinosa Kozur and Mostler, 1979 & + & + \\
\hline Zhamojdasphaera latispinosa mersinensis Kozur, Moix and Mostler, 2007 & + & + \\
\hline Zhamojdasphaera rigoi brevispinosa Kozur, Moix and Mostler, 2007 & + & + \\
\hline Zhamojdasphaera rigoi Kozur, Moix and Mostler, 2007 & + & + \\
\hline \multicolumn{3}{|l|}{ Order Entactinaria Kozur and Mostler 1982} \\
\hline Carinaheliosoma carinata (Kozur and Mostler, 1979) & & + \\
\hline Coronatubopyle denticulata Dumitrica and Tekin, 2010 & + & \\
\hline Coronatubopyle omanensis Dumitrica and Tekin, 2009 & + & \\
\hline Coronatubopyle sp. cf. C. omanensis Dumitrica and Tekin, 2010 & + & \\
\hline Coronatubopyle spelae Dumitrica and Tekin, 2010 & + & \\
\hline Hexapylomella carnica Kozur and Mostler, 1979 & + & \\
\hline Hindeosphaera burri Ozsvárt, Moix and Kozur, 2015 & + & + \\
\hline Hindeosphaera cf. H. goestlingensis Kozur and Mostler, 1979 & + & \\
\hline Hindeosphaera djani Ozsvárt, Moix and Kozur, 2015 & + & \\
\hline Hindeosphaera foremanae Kozur and Mostler, 1979 & + & \\
\hline Hindeosphaera naomiae Ozsvárt, Moix and Kozur, 2015 & + & \\
\hline Hindeosphaera sp. & + & \\
\hline Kahlerosphaera abnormis Kozur, Moix and Ozsvárt, 2007b & + & \\
\hline Kahlerosphaera faludyi Kozur, Moix and Ozsvárt, 2007b & + & \\
\hline Kahlerosphaera hamvasi Kozur, Moix and Ozsvárt, 2007b & + & \\
\hline Kahlerosphaera karinthyi Kozur, Moix and Ozsvárt, 2007b & + & + \\
\hline Kahlerosphaera kerteszi Kozur, Moix and Ozsvárt, 2007b & + & + \\
\hline Kahlerosphaera koestleri Kozur, Moix and Ozsvárt, 2007b & + & + \\
\hline Kahlerosphaera pamuki Kozur, Moix and Ozsvárt, 2007b & + & \\
\hline Kahlerosphaera rejtoei Kozur, Moix and Ozsvárt, 2007b & + & + \\
\hline Kahlerosphaera szerbi Kozur, Moix and Ozsvárt, 2007b & + & \\
\hline Kahlerosphaera vonneguti Kozur, Moix and Ozsvárt, 2007b & + & + \\
\hline Parentactinia pugnax Dumitrica, 1978 & + & + \\
\hline Pentactinocarpus acanthicus Dumitrica, 1978 & + & + \\
\hline Pentactinocarpus magnus (Kozur and Mostler, 1979) & + & \\
\hline Pentactinocarpus tetracanthus Dumitrica, 1978 & + & \\
\hline Pentactinorbis cf. P. megasphaera (Sugiyama, 1997) & + & \\
\hline Pentactinorbis pessagnoi Kozur and Mostler, 1994 & + & \\
\hline Pseudostylosphaera dumitricai Ozsvárt, Moix and Kozur, 2015 & + & + \\
\hline Pseudostylosphaera longispinosa Kozur and Mostler, 1981 & + & \\
\hline Spinostylosphaera andrasi Ozsvárt, Moix and Kozur, 2015 & + & + \\
\hline Spinostylosphaera andrasi brevispinata Ozsvárt, Moix and Kozur, 2015 & + & + \\
\hline Spinostylosphaera masseti $\mathrm{n} . \mathrm{sp}$. & + & \\
\hline Spinostylosphaera mesotriassica (Dumitrica, Kozur and Mostler, 1980) & + & \\
\hline Spinostylosphaera michelae $\mathrm{n} . \mathrm{sp}$. & + & \\
\hline Spinostylosphaera sengoeri $\mathrm{n} . \mathrm{sp}$. & + & \\
\hline Spinostylosphaera vachardi Ozsvárt, Moix and Kozur, 2015 & + & \\
\hline Spinostylosphaera vachardi elongata Ozsvárt, Moix and Kozur, 2015 & + & \\
\hline \multicolumn{3}{|l|}{ Order Nasselaria Ehrenberg 1875} \\
\hline Alatipicapora latoalata Kozur, Moix and Ozsvárt, 2007c & + & \\
\hline Alatipicapora spinosa Kozur, Moix and Ozsvárt, 2007c & + & \\
\hline Alatipicapora tetrapedis Kozur, Moix and Ozsvárt, 2007c & + & \\
\hline
\end{tabular}


Table 1 (Continued)

\begin{tabular}{|c|c|c|}
\hline Radiolarian species from & Sorgun Ophiolitic Mélange & Kopría Mélange, Rhodes \\
\hline Annulohaeckeliella curvispina nov. sp. & & + \\
\hline Annulohaeckeliella rectospina nov. sp. & & + \\
\hline Annulopoulpus gibber nov. sp. & & + \\
\hline Annulopoulpus parviaperturus (Kozur and Mostler, 1979) & + & + \\
\hline Annulopoulpus reticulatus Kozur and Mostler, 1981 & + & + \\
\hline Archaeosemantis multispinosa n. sp. & + & \\
\hline Aropeon cingulatus nov. sp. & & + \\
\hline Aropeon cinguloporatus nov. sp. & & + \\
\hline Aropeon graecorus nov. sp. & & + \\
\hline Bulbocyrtium reticulatum Kozur and Mostler, 1981 & & + \\
\hline Caponabolella brevispinosa nov. gen. nov. sp. & + & + \\
\hline Caponabolella longispinosa nov. gen. nov. sp. & + & + \\
\hline Circopoulpus cornubovis nov. sp. & + & + \\
\hline Circopoulpus dulaii nov. sp. & + & + \\
\hline Circulopoulpus bisulcatus nov. sp. & & + \\
\hline Coronatubopyle denticulata Dumitrica and Tekin, 2010 & + & \\
\hline Coronatubopyle omanensis Dumitrica and Tekin, 2010 & + & \\
\hline Coronatubopyle spelae Dumitrica and Tekin, 2010 & + & \\
\hline Eonapora pulchra Kozur and Mostler, 1979 & + & \\
\hline Hinedorcus elegantissimus (Tekin, 1999) & + & \\
\hline Hinedorcus robustus (Kozur and Mostler, 1981) & + & + \\
\hline Hypoxiphothecaella claviformis Kozur, Moix and Ozsvárt, 2007a & + & \\
\hline Hypoxiphothecaella elongata Kozur, Moix and Ozsvárt, 2007a & + & \\
\hline Hypoxiphothecaella foezyi Kozur, Moix and Ozsvárt, 2007a & + & \\
\hline Hypoxiphothecaella inflata Kozur, Moix and Ozsvárt, 2007a & + & \\
\hline Hypoxiphothecaella mersinensis Kozur, Moix and Ozsvárt, 2007a & + & \\
\hline Minicrampus longispinosus n. gen. n. sp. & + & \\
\hline Nabolella thoraxaca nov. sp. & + & + \\
\hline Neopylentonema procera Sugiyama, 1997 & + & \\
\hline Pararuesticyrtium longispinosum Kozur, Moix and Ozsvárt, 2007a & + & \\
\hline Pararuesticyrtium mersinensis Kozur, Moix and Ozsvárt, 2007a & + & + \\
\hline Podobursa claviformis Kozur, Moix and Ozsvárt, 2007c & + & \\
\hline Podobursa fusiformis Kozur, Moix and Ozsvárt, 2007c & + & + \\
\hline Podobursa longiceras Kozur, Moix and Ozsvárt, 2007c & + & \\
\hline Podobursa longiceras tetraspinosa Kozur, Moix and Ozsvárt, 2007c & + & \\
\hline Podobursa mersinensis Kozur, Moix and Ozsvárt, 2007c & + & + \\
\hline Podobursa sceptrumides Kozur, Moix and Ozsvárt, 2007c & + & \\
\hline Podobursa tuvalica Kozur, Moix and Ozsvárt, 2007c & + & \\
\hline Poulpus compactus nov. sp. & + & \\
\hline Poulpus elegans nov. sp. & + & \\
\hline Poulpus kozuri nov. sp. & + & \\
\hline Poulpus norica (Kozur, Moix and Ozsvárt, 2007c) & + & \\
\hline Poulpus oertlii (Kozur and Mostler, 1979) & + & \\
\hline Poulpus phasmatodes De Wever, 1979 & + & \\
\hline Poulpus piabyx De Wever in De Wever et al., 1979 & + & + \\
\hline Poulpus rhodoensis nov. sp. & & + \\
\hline Poulpus sulcatospinosus nov. sp. & + & \\
\hline Poulpus transitus Kozur and Mostler, 1981 & + & \\
\hline Poulpus transitus Kozur and Mostler, 1981 & + & \\
\hline Pseudosaturniforma carnica Kozur and Mostler, 1979 & + & \\
\hline Ruesticyrtium coronatum Kozur, Moix and Ozsvárt, 2007a & + & + \\
\hline Ruesticyrtium georgi Kozur, Moix and Ozsvárt, 2007a & + & + \\
\hline Ruesticyrtium georgi novemdentatum Kozur, Moix and Ozsvárt, 2007a & + & \\
\hline Ruesticyrtium latidentatum Kozur, Moix and Ozsvárt, 2007a & + & + \\
\hline Ruesticyrtium lobatum Kozur, Moix and Ozsvárt, 2007a & + & \\
\hline Ruesticyrtium mostleri Kozur, Moix and Ozsvárt, 2007a & + & \\
\hline Silicarmiger longospinosus nov. sp. & + & + \\
\hline Spinomersinella goricanae Kozur, Moix and Ozsvárt, 2007c & + & \\
\hline Spinomersinella multispinosa Kozur, Moix and Ozsvárt, 2007c & + & \\
\hline Spinoprotunuma? constricta Kozur, Moix and Ozsvárt, 2007c & + & + \\
\hline Spinoprotunuma? furcatostriata Kozur, Moix and Ozsvárt, 2007c & + & \\
\hline Spinoprotunuma triassica Kozur, Moix and Ozsvárt, 2007c & + & + \\
\hline Stampfliella tuvalica Kozur, Moix and Ozsvárt, 2007c & + & \\
\hline Syringocapsa glabra Kozur, Moix and Ozsvárt, 2007c & + & \\
\hline
\end{tabular}

Please cite this article in press as: Ozsvárt, P., et al., Mono- and dicyrtid Nassellaria (Radiolaria) from the Upper Carnian of the Sorgun Ophiolitic Mélange, Southern Turkey and Kopría Mélange, Rhodes, Greece. Revue de micropaléontologie (2016), http://dx.doi.org/10.1016/j.revmic.2016.11.004 
Table 1 (Continued)

\begin{tabular}{lll}
\hline Radiolarian species from & Sorgun Ophiolitic Mélange & Kopría Mélange, Rhodes \\
\hline Tekinium bragini nov. sp. & + & + \\
Tekinium robustum nov. sp. & & + \\
Veghicyclia reiflingensis Kozur and Mostler, 1972 & + & + \\
Veloruesticyrtium palfyi Kozur, Moix and Ozsvárt, 2007a & + & + \\
Xiphothecaella brevicaudata Kozur, Moix and Ozsvárt, 2007a & + & + \\
Xiphothecaella elegans Kozur, Moix and Ozsvárt, 2007a & + & + \\
Xiphothecaella longicaudata Kozur, Moix and Ozsvárt, 2007a & + & + \\
Xiphothecaella orchardi Kozur, Moix and Ozsvárt, 2007a & + & + \\
Xiphothecaella procera Kozur, Moix and Ozsvárt, 2007a & & + \\
\hline
\end{tabular}

and by the fact that the three cephalic arches are well marked by ridges.

Etymology: In allusion to its dumpy appearance.

Range and occurrence: Lower Tuvalian (Spongotortilispinus moixi Zone) of the Sorgun Ophiolitic Mélange, Turkey.

Poulpus elegans Ozsvárt, Dumitrica \& Hungerbuhler nov. sp.

Plate 1, fig. 3

Description: Cephalis hemispherical, very small and low, without apical horn and with nodulose surface. Collar ridge thick with high rim-like structure. Cephalic pore at base of feet not visible but it should have existed. Thorax long, its length approximately three times the length of cephalis, cylindrical, smooth surfaced, with tiny irregularly shaped pores and ragged distal end. Feet long, pointed, three-bladed, with two blades external and one internal and slightly twisted. Their external groove is only visible on the proximal end after which it gradually disappears. Feet start in lateral direction and soon bend in distal direction about $90^{\circ}$ or more tending to get nearer to one another distally.

Material: More than 10 specimens.

Holotype: The specimen in pl. 1, fig. 3, HNHM, PAL 2016.18.

Dimensions (in $\mu \mathrm{m}$ based on 2 specimens): Height of cephalis 63-68, diameter of cephalis 93-111, length of feet 298-333.

Remarks: Poulpus elegans nov. sp. differs from all the other species of Poulpus with apertural ridge by having significantly smaller cephalis and characteristically bent feet.

Etymology: In allusion to its graceful appearance.

Range and occurrence: Lower Tuvalian (Spongotortilispinus moixi Zone) of the Sorgun Ophiolitic Mélange, Turkey.

Poulpus kozuri Ozsvárt, Dumitrica \& Hungerbuhler nov. sp. Plate 1, figs. 4-5

Description: Cephalis large, globular without apical horn; its wall is smooth-surfaced and has tiny and rare pores. Feet equal, downwardly curved and distally pointed; they have, it seems, only two blades that bend sideways creating a deep internal groove. Collar ring thick running between two feet and forming a narrow tunnel where the feet are connected to the cephalis. Probable pores on cephalis accompanying the rays D and $2 \mathrm{~L}$ not observed due to the position of feet on photo or covered by foreign material.

Material: More than 5 specimens.
Holotype: The specimen in Pl. 1, figs. 4-5, HNHM, PAL 2016.19.

Dimensions (in $\mu \mathrm{m}$ based on 2 specimens): Height of cephalis 69-73, diameter of cephalis 64-74, length of feet 148-185.

Remarks: Poulpus kozuri nov. sp. differs from the other species of the genus with bladed feet in having only two blades and these blades being rolled up to form a groove.

Etymology: In honour of Heinz W. Kozur, who was an outstanding expert on radiolarians, conodonts, ostracods, conchostracans and on the Triassic System.

Range and occurrence: Lower Tuvalian (Spongotortilispinus moixi Zone) of the Sorgun Ophiolitic Mélange, Turkey.

\section{Poulpus oertlii (Kozur and Mostler, 1979)}

Plate 2, fig. 3

1979 Parapoulpus oertlii nov. sp. - Kozur and Mostler, p. 88, pl. 7, fig. 5.

1981 Parapoulpus oertlii Kozur \& Mostler - Kozur and Mostler, p. 81, pl. 26, fig. 2.

2009 Poulpus oertlii (Kozur \& Mostler) - O’Dogherty et al., p. 249 , fig. 258.

Remarks: According to O'Dogherty et al. (2009) the genus Parapoulpus Kozur and Mostler (1979) is a synonym of Poulpus De Wever. We use herein this new generic status. It is, however, strange that all specimens of this species have a long cylindrical thorax, proving that the presence of this segment is characteristic of this species.

Range and occurrence: Upper Cordevolian, Tetraporobrachia haeckeli Zone, Großreifling (Northern Calcareous Alps, Austria) and lower Tuvalian (Spongotortilispinus moixi Zone) of the Sorgun Ophiolitic Mélange, Turkey.

Poulpus piabyx De Wever, 1979

Plate 1, figs. 6-11

1979 Poulpus piabyx nov. sp. - De Wever in De Wever et al., p. 98 , pl. 7, fig. 12.

1979 Poulpus piabyx De Wever - Kozur and Mostler, p. 87, pl. 4 , fig. 3.

1981 Poulpus piabyx De Wever - Kozur and Mostler, pl. 30, fig. 5 .

1982 Poulpus piabyx De Wever - De Wever, p. 328, pl. 48, figs. 5,6 .

1984 Poulpus piabyx De Wever - De Wever, pl. 3, figs. 3, 4. 


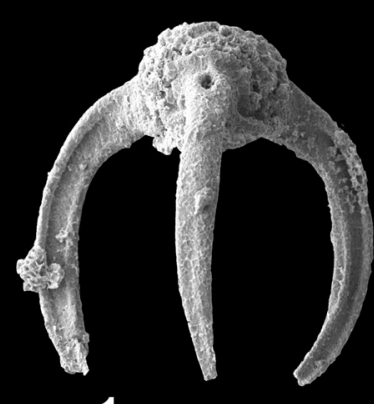

1

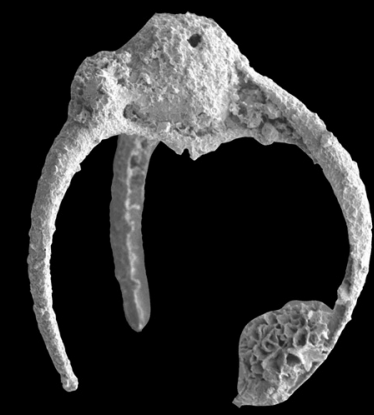

4
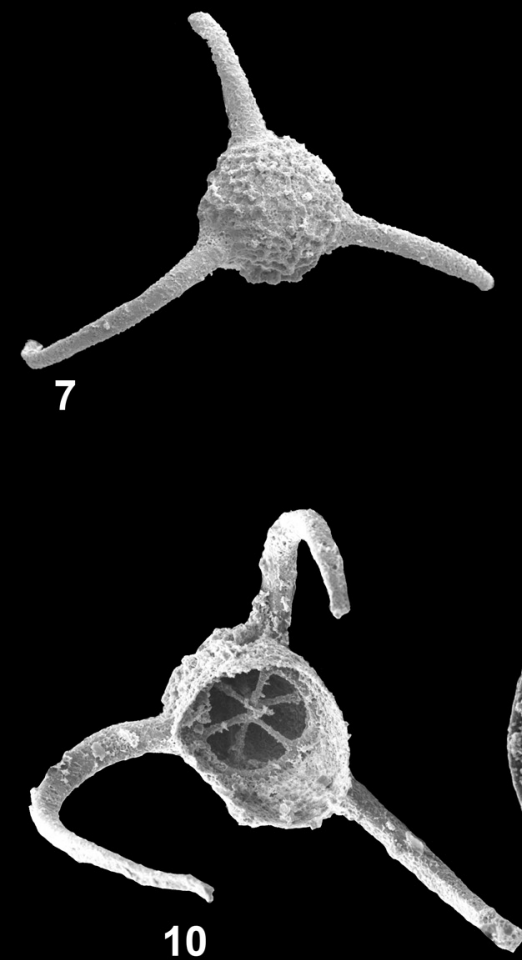

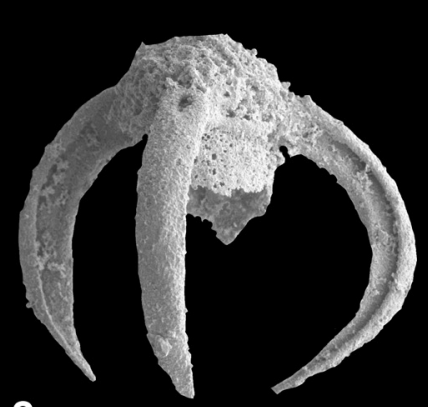

2
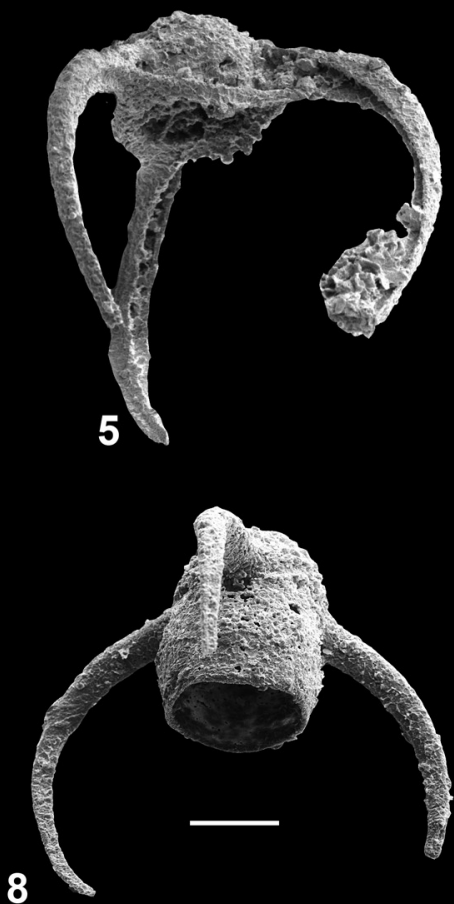

8

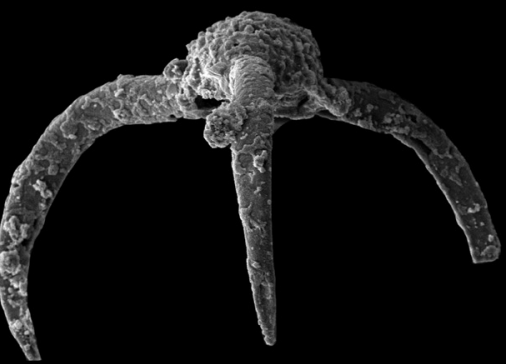

11
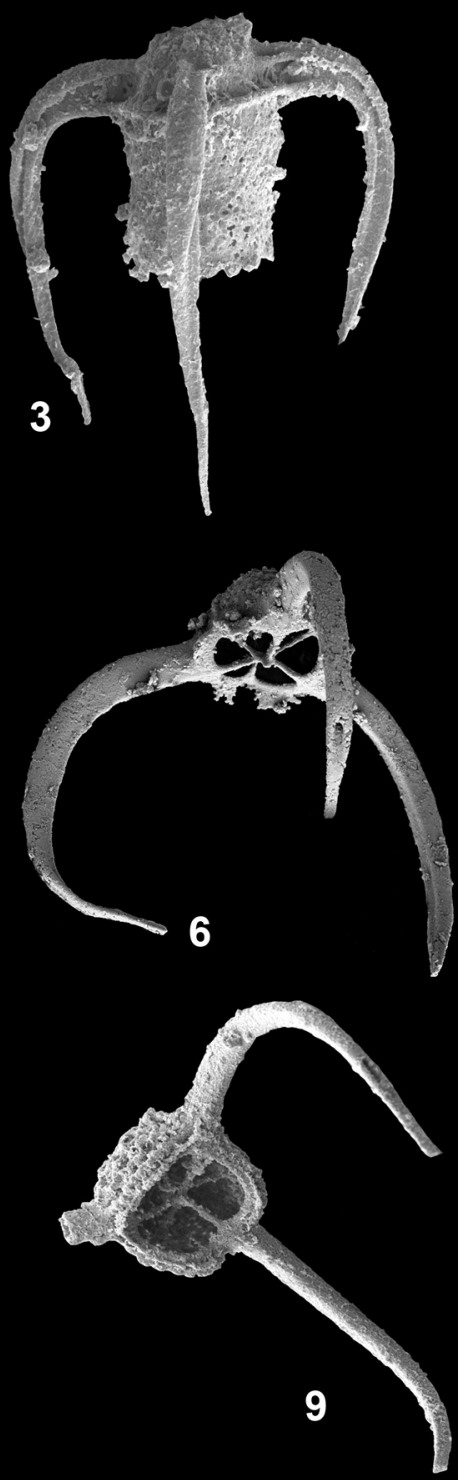

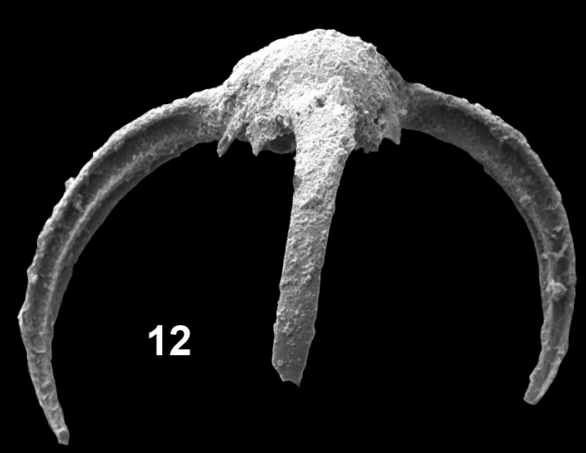

Plate 1. 1-2. Poulpus compactus Ozsvárt, Dumitrica \& Hungerbuhler nov. sp. (Sorgun Ophiolitic Mélange, Turkey). 3. Poulpus elegans Ozsvárt, Dumitrica \& Hungerbuhler nov. sp. (Sorgun Ophiolitic Mélange, Turkey). 4-5. Poulpus kozuri Ozsvárt, Dumitrica \& Hungerbuhler nov. sp. (Sorgun Ophiolitic Mélange, Turkey). 6-11. Poulpus piabyx De Wever (6. from Kopría Mélange, Rhodes, Greece; 7-11. Sorgun Ophiolitic Mélange, Turkey). 12. Poulpus phasmatodes De Wever. Scale bar $=50 \mu \mathrm{m}$.

Please cite this article in press as: Ozsvárt, P., et al., Mono- and dicyrtid Nassellaria (Radiolaria) from the Upper Carnian of the Sorgun Ophiolitic Mélange, Southern Turkey and Kopría Mélange, Rhodes, Greece. Revue de micropaléontologie (2016), http://dx.doi.org/10.1016/j.revmic.2016.11.004 


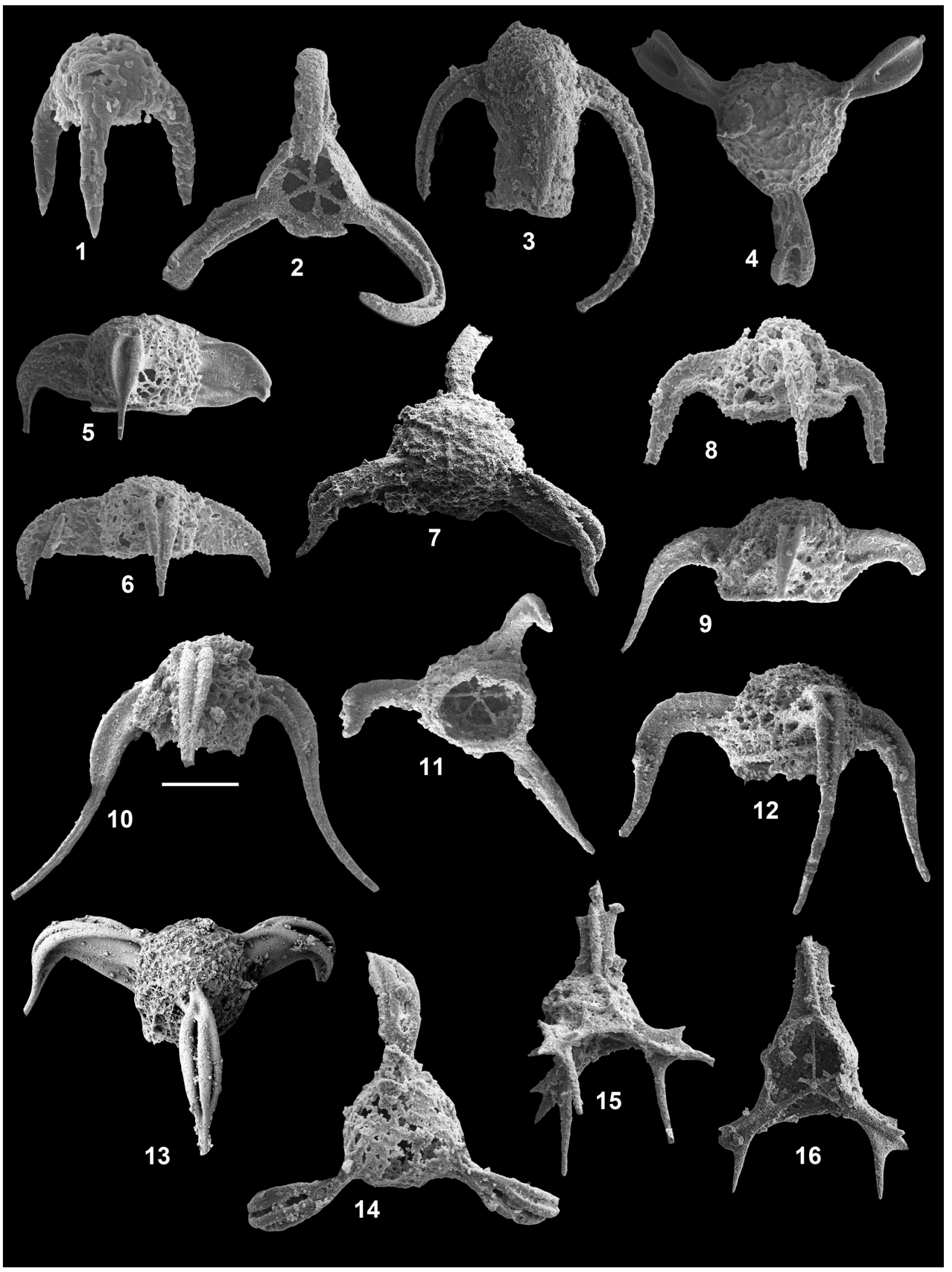

Plate 2. 1. Poulpus rhodoensis Ozsvárt, Dumitrica \& Hungerbuhler nov. sp. (Kopría Mélange, Rhodes, Greece). 2. Poulpus transitus Kozur and Mostler (Sorgun Ophiolitic Mélange, Turkey). 3. Poulpus oertlii (Kozur \& Mostler) (Sorgun Ophiolitic Mélange, Turkey). 4-7. Circopoulpus dulaii Ozsvárt, Dumitrica \& Hungerbuhler nov. sp. (4-6. Kopría Mélange, Rhodes, Greece; 7. Sorgun Ophiolitic Mélange, Turkey). 8-12. Circopoulpus cornubovis Ozsvárt, Dumitrica \& Hungerbuhler nov. sp. (8. Kopría Mélange, Rhodes, Greece; 9-12. Sorgun Ophiolitic Mélange, Turkey). 13-14. Circopoulpus bisulcatus Ozsvárt, Dumitrica \& Hungerbuhler nov. sp. (Kopría Mélange, Rhodes, Greece). 15-16. Neopylentonema procera Sugiyama (Sorgun Ophiolitic Mélange, Turkey). Scale bar $=100 \mu \mathrm{m}$.

Please cite this article in press as: Ozsvárt, P., et al., Mono- and dicyrtid Nassellaria (Radiolaria) from the Upper Carnian of the Sorgun Ophiolitic Mélange, Southern Turkey and Kopría Mélange, Rhodes, Greece. Revue de micropaléontologie (2016), http://dx.doi.org/10.1016/j.revmic.2016.11.004 
1990 Poulpus piabyx De Wever - Yeh, pl. 8, figs. 3, 7, 9. 1997 Poulpus piabyx De Wever - Sugiyama, fig. 49-15.

1999 Poulpus piabyx De Wever - Bragin \& Krylov, p. 558, figs. 10A-C. 4.

1999 Poulpus piabyx De Wever - Tekin, p. 160, pl. 38, figs. 3,

2002 Poulpus piabyx De Wever - Wang et al., p. 331, pl. 2, figs. 30-34.

2007 Poulpus piabyx De Wever - Bragin, p. 1004, pl. 16, fig. 6 .

2007a Poulpus piabyx De Wever-Tekin and Bedi, p. 183, pl. 3, figs. 16, 17.

Remarks: However, in the original description (De Wever, in De Wever et al., 1979) it is clearly pointed out that the test contains a subhemispherical cephalis and three downwardly curved feet and that the circular mouth is smooth, without lobes, the perfectly preserved radiolarian fauna from the Sorgun Ophiolitic Mélange contains many specimens of Poulpus piabyx De Wever that wear a fragile thorax (Pl. 1, figs. 8, 10) with extremely thin wall that can or cannot be preserved in case of poorer preservation. In some cases, a partially preserved thin wall on the mouth can be observed (Pl. 1, fig. 9), and only in few cases, the thorax is complete (Pl. 1, figs. 8, 10). The thorax is tubular, smooth with tiny irregularly disposed pores.

Range and occurrence: Lower Carnian to lower Norian, cosmopolitan species in the tropical region.

\section{Poulpus phasmatodes De Wever, 1979}

Plate 1, fig. 12

1979 Poulpus phasmatodes nov. sp. - De Wever in De Wever et al., p. 96, pl. 7, figs. 10, 11

1979 Poulpus phasmatodes De Wever - Kozur and Mostler, p. 87 , pl. 7 , fig. 6 , pl. 16 , fig. 1

1981 Poulpus phasmatodes De Wever - Kozur and Mostler, pl. 33, fig. 1

1982 Poulpus phasmatodes De Wever - De Wever, p. 327, pl. 48 , figs. 2,3

Remarks: The illustrated specimen wears a slightly compressed and smooth cephalis with six triangular-shaped protuberances. The three long feet are strongly curved and Tshaped in cross-section, and wear sharp ridges with a slightly widening groove at the proximal end.

Range and occurrence: Lower Carnian to lower Norian in the Tethyan realm.

Poulpus rhodoensis Ozsvárt, Dumitrica \& Hungerbuhler nov. sp.

Plate 2, fig. 1

Description: Test rather simple consisting of a hemispherical cephalis with a very short cylindrical skirt and 3 three-bladed pointed feet. Cephalis rather smooth, without apical horn. It bears 3 stout feet arising in antapical direction from the base of cephalis so that they are practically parallel. Feet rounded in cross section in the proximal half or third and hollow, than they become three-bladed having a narrow groove externally between two thick blades and also an internal blade. The opening of the inner cavity of the proximal part of feet is well marked at the beginning of the groove. In the distal half feet are gradually pointing. Under the cephalic collar, a very short cylindrical skirt is developed. Its structure is not well visible because of poor preservation.

Material: More than 10 specimens.

Holotype: The specimen in Pl. 2, fig. 1, coll. MGL nr. 97929.

Dimensions (in $\mu \mathrm{m}$ based on 2 specimens): Height of cephalis $30-45$, diameter of cephalis 50-58, length of feet 60-80.

Remarks: This species differs from the other species of the genus Poulpus by having short and antapically directed feet, which are practically parallel. With its short skirt it reminds the species Parapoulpus oertlii (Kozur and Mostler, 1979), a genus which is now considered a synonym of Poulpus (O'Dogherty et al., 2009).

Etymology: The species is named from its occurrence in the Rhodes Island.

Range and occurrence: Very rare in the lower Tuvalian, Spongotortilispinus moixi Zone, Kopría Mélange, Rhodes Island, Greece.

\section{Poulpus transitus Kozur and Mostler, 1981}

Plate 2, fig. 2

1981 Poulpus transitus nov. sp.-Kozur and Mostler, p. 81, pl. 29, fig. 2, pl. 31, fig. 3 .

1999 Poulpus transitus Kozur \& Mostler - Tekin, p. 160, pl. 38, fig. 5.

2007 Poulpus transitus Kozur \& Mostler - Bragin, p. 1005, pl. 12, figs. 7,8 .

Remarks: One of the illustrated specimens from the Sorgun Ophiolitic Mélange differs from the holotype of $P$. transitus Kozur and Mostler, 1981 by having a complete, tubular thorax with rounded pores. The strongly curved feet wear three, narrow grooves. The specimens from the Sorgun Mélange resemble perfectly the topotype specimens.

Range and occurrence: Lower Carnian (Julian) of Großreifling (Northern Calcareous Alps, Austria) and lower Tuvalian (Spongotortilispinus moixi Zone) of the Sorgun Ophiolitic Mélange, Turkey to lower Norian from the Yaylakuzdere Measured section, Alakircay Nappe, Antalya Nappes, Kemer, Antalya, Turkey and from Mamonia Complex, southwestern Cyprus.

Genus Circopoulpus Ozsvárt, Dumitrica \& Hungerbuhler nov. gen.

Type species: Circopoulpus dulaii Ozsvárt, Dumitrica \& Hungerbuhler nov. sp.

Diagnosis: Skeleton consisting of a hornless cephalis with 3 feet and a wide distal apertural ring. Feet situated above the apertural ring, three- or four-bladed and separated by grooves. External groove that can start in the vicinity of cephalis or at a certain distance from it, is connected with the pore that accompanies the rays $\mathrm{D}$ and $2 \mathrm{~L}$ either directly or through a canal inserted in the feet. Collar plate with its 6 pores is above the apertural ring. A velum-like cylindrical thoracic segment may be sometimes developed. 
Remarks: This new genus is somehow intermediary between the genera Poulpus De Wever, Veghia Kozur \& Mostler, and Annulopoulpus Kozur and Mostler, 1981. With Poulpus, it has in common the pore near the feet $\mathrm{D}$ and $2 \mathrm{~L}$, an external groove and a rather low cephalis. With Veghia, it has in common the general shape, the presence of an apertural ring, but differs from it because Veghia has no cephalic pore connected with feet $\mathrm{D}$ and $2 \mathrm{~L}$ and the odd blade is external. With Annulopoulpus, it has in common the circular aperture, the similar position of the blades of feet, but differs in having no cephalic pore connected to feet. Also, the species of this new genus differs from the species of the other 3 genera in the shape of feet, their distal ends being outwardly recurved.

Etymology: From the Latin circus-circle, and the genus name Poulpus. Masculine gender.

Range: Lower Tuvalian so far as known.

\section{Circopoulpus dulaii Ozsvárt, Dumitrica \& Hungerbuhler nov.} sp.

Plate 2, figs. 4-7.

Description: Test subglobular in lateral view but triangular in apical view, without apical horn. Outer layer of cephalic wall consisting of larger polygonal pore frames; inner layer with tiny circular pores. Cephalic spicular system located at the upper part of the cephalis. Thorax, when present, fragile, thin-walled with polygonal pores connected to the characteristic ring-like collar structure. The three feet in prolongation of $\mathrm{D}$ and $2 \mathrm{~L}$ are similar, three-bladed and very broad in vertical plane, extended from above the apertural ring to the upper part of cephalis. Outer groove through which the cephalic cavity is connected with the exterior starts at a certain distance from cephalis. Up to that distance the connection is effected through a canal situated toward the upper part of feet, which is easily recognized externally by a thickness of the vertical blade. Feet short, broad and outwardly directed on a short portion, then are quickly narrowing and bent downwardly at about $90^{\circ}$, and terminated in a needle-shaped spine.

Material: More than 5 specimens.

Holotype: The specimen in Pl. 2, fig. 5, coll. MGL nr. 97930.

Dimensions (in $\mu \mathrm{m}$ based on 5 specimens): Height of cephalis 100-125, diameter of cephalis 83-125, length of feet 138-277.

Remarks: Circopoulpus dulaii nov. sp. resembles very much Circopoulpus bisulcatus nov. sp. from which it only differs by having a single external groove on feet. One illustrated specimen (pl. 2, fig. 4) exhibits on the surface of the apical part of cephalis the three arches $\mathrm{AV}$ and $2 \mathrm{Al}$ well expressed on some species of Poulpus.

Etymology: In honor of Dr. Alfréd Dulai, Head of the Department of Paleontology and Geology, Hungarian Natural History Museum, Budapest.

Range and occurrence: Lower Tuvalian (Spongotortilispinus moixi Zone) of the Kopría Mélange, Rhodes, and Sorgun Ophiolitic Mélange, Turkey.

Circopoulpus cornubovis Ozsvárt, Dumitrica \& Hungerbuhler nov. sp.

\section{Plate 2, figs. 8-12}

Description: Cephalis hemispherical, small with a more or less well marked apertural ring. Surface as with the genus, consisting of two layers, of which the outer one has polygonal pores. Feet long, four-bladed on the proximal portion, with two bladed external and two internal and directed laterally in the short proximal portion, than fast downwardly curved and thinning gradually distally and also gradually curving outward. Thoracic velum cylindrical, thin and not always preserved.

Material: More than 20 specimens.

Holotype: The specimen in Pl. 2, fig. 12, HNHM, PAL 2016.21.1.

Dimensions (in $\mu \mathrm{m}$ based on 7 specimens): Height of cephalis 100-118, diameter of cephalis 85-102, length of feet 246-296.

Remarks: This new species resembles Circopoulpus dulaii nov. sp. from which it differs in having longer feet and a much narrower proximal portion that does not extend on the whole height of cephalis.

Etymology: In Latin, from the resemblance of its feet with the horns of a beef.

Range and occurrence: Lower Tuvalian, Spongotortilispinus moixi Zone, Kopría Mélange, Rhodes Island, Greece, and Sorgun Mélange, Turkey.

\section{Circopoulpus bisulcatus Ozsvárt, Dumitrica \& Hungerbuhler} nov. sp.

Plate 2, fig. 13-14

Description: Cephalis hemispherical prolonged into a short and thin-walled cylindrical thorax. Cephalis thick-walled with nodular surface, nodule interconnected by very thin crests, when very well preserved, giving its surface a star covered aspect. Same ornamentation on thorax the ornamentation of which consists usually of transversal ribs with usually square and very small pores. Distal margin of thorax ragged. Shape of cephalic opening unknown due to the position of the specimen on the stub. Without apical horn. Feet robust, very broad in vertical plane, bearing on the outer part 3 unequal ribs, two starting in the vicinity of the cephalic wall, the third resulting from the bifurcation of one rib, which is always the rib behind the simple one in apical view and in clockwise sense. This results in feet having a deeper and longer groove and a less deep and shorter one. Axial part of proximal portion of feet thickened proximally; this thickened part along spines seems to correspond to a canal connecting the inner cavity of cephalis with the external groove of the feet. This longitudinal thickness is well visible when the feet are laterally viewed. Distal part of feet narrower and pointed. Due to the bifurcation of one rib feet are navicular in apical view. On the proximal half they are straight, completely laterally directed and very broad in vertical plane, after which they are suddenly downwardly bent at about $90^{\circ}$, thinning and terminated in a thin beak-shaped and slightly recurved distal spine.

Material: Two specimens from the Kopría Mélange, Rhodes, Greece.

Holotype: The specimen in Pl. 2, fig. 13, coll. MGL nr. 97932.

Dimensions (in $\mu \mathrm{m}$ based on 2 specimens): Height of cephalis 115-125, diameter of cephalis 100-110, length of feet 210-225. 
Remarks: The species was compared to Circopoulpus dulaii nov. sp. under the latter, with which it resembles significantly. Due to this resemblance, at the beginning, when we had had a single specimen we had thought that it represent an anomaly of C. dulaii. Finding of a second specimen, the paratype, proved that it represents an independent species.

Etymology: In Latin, from having two grooves (sulcus, -sulci) on the external side of feet.

Range and occurrence: Extremely rare in the lower Tuvalian (Spongotortilispinus moixi Zone) of the Kopría Mélange, Rhodes, Greece.

Genus Neopylentonema Kozur, 1984

Type species: Neopylentonema mesotriassica Kozur, 1984

Neopylentonema procera Sugiyama, 1997

Plate 2. figs. 15-16

1989 Poulpus (?) sp. C - Yeh, p. 74, pl. 6, figs. 5, 10.

1997 Neopylentonema procera nov. sp. - Sugiyama, p. 161, figs. 46-3a, b.

1999 Neopylentonema sp. aff. N. procera Sugiyama, 1997 Bragin and Krylov, p. 558, fig. 10E.

2007 Neopylentonema procera Sugiyama - Bragin, p. 1005, pl. 12, fig. 9.

Remarks: The broken specimen illustrated in pl. 2, fig. 16 exhibits the initial spicule system with MB, A, 2L, 21, and D. In describing this species Sugiyama mentioned erroneously that the spines have a verticil of 3 branches. In fact, the spines of this species have 4 blades and the verticils of 4 spinules, respectively.

Range and occurrence: Cosmopolitan species in the tropical region from the lower Tuvalian (Spongotortilispinus moixi Zone) of the Sorgun Ophiolitic Mélange, Turkey, and Kopría Mélange, Rhodes, to lower Norian.

Genus Annulopoulpus Kozur and Mostler, 1981

Type species: Annulopoulpus costatus Kozur and Mostler, 1981

Annulopoulpus parviaperturus (Kozur and Mostler, 1979)

Plate 3, figs. 1-5

1979 Parapoulpus parviaperturus nov. sp. - Kozur and Mostler, p. 89, pl. 7, fig. 4; pl. 16, fig. 2.

1981 Annulopoulpus parviaperturus (Kozur \& Mostler) Kozur and Mostler, p. 84, pl. 32, fig. 1.

1981 Annulopoulpus reticulatus nov. sp. - Kozur and Mostler, p. 84, pl. 31, fig. 2.

1999 Annulopoulpus reticulatus Kozur \& Mostler - Tekin, p. 158, pl. 37, fig. 4.

?1999 Annulopoulpus antalyaensis nov. sp. - Tekin, p. 158, pl. 37, figs. 1-3, 5 .

2007 Annulopoulpus parviaperturus (Kozur \& Mostler) Tekin and Bedi, p. 183, pl. 3, figs. 13, 14.

Remarks: We synonymize herein the species Annulopoulpus reticulatus Kozur and Mostler, 1981 with Parapoulpus parviaperturus Kozur and Mostler, 1979 because we see no differences between the holotypes of the two species, and the latter has priority. Both have the same superficial ornamentation, the same double apertural ring and the same type of feet. The early Norian species Annulopoulpus antalyaensis Tekin, 1999 with its wider apertural ring and larger cephalis, could be a different species; unfortunately, the basal positions in which this species have been illustrated do not allow seeing the shape of the cephalis in lateral view because some images would suggest that the cephalis is not perfectly spherical but flat. In our samples we found two morphotypes: spherical (pl. 3, figs.?1, 4, 5) and ovate (pl. 3, figs. 2, 3). Since all the other characters are similar we considered them conspecific in the present state of knowledge.

Range and occurrence: Lower Carnian (Julian) of Großreifling (Northern Calcareous Alps, Austria) and upper Carnian (early Tuvalian, Spongotortilispinus moixi Zone) of the Sorgun Ophiolitic Mélange, Turkey, and Kopría Mélange, Rhodes, Greece, to probably lower Norian from the Yaylakuzdere Measured section, Alakircay Nappe, Antalya Nappes, Kemer, Antalya, Turkey.

Annulopoulpus gibber Ozsvárt, Dumitrica \& Hungerbuhler nov. sp.

Plate 3, figs. 6-7

Description: Cephalis short, conical above the feet, with the widest diameter at the level of the base of feet and constricted distally, with a wide aperture with double circular rings. Wall double-layered; inner layer with small, circular to ovate small pores, outer layer strongly reticulate, reticulations representing the outer layer wall and consisting of nodes interconnected by bars that form triangular to quandrangular meshes. Feet short, robust, antapically directed; they are four-bladed, with two inner blades and two external. Grooves between internal blades and between internal and external blades deep and narrow. Space between outer blades is convex on the proximal half, than slightly concave and at the same time feet start narrowing to terminate in a thin conical spine.

Material: Two specimens from the Kopría Mélange, Rhodes, Greece.

Holotype: The illustrated specimen in P1. 3., figs. 6-7 (same specimen in two views), coll. MGL nr. 97933.

Dimensions (in $\mu \mathrm{m}$ based on 2 specimens): Height of cephalis 130-140, diameter of cephalis 120-130, length of feet 120-140.

Remarks: Annulopoulpus gibber nov. sp. resembles Annulopoulpus parviaperturus (Kozur \& Mostler) in having a reticulate surface but differs from it in having a shorter and hunched cephalis, and feet shorter and thicker.

Etymology: From the Latin gibber, -era, -erum-hunched.

Range and occurrence. Very rare in the lower Tuvalian, Spongotortilispinus moixi Zone, Kopría Mélange, Rhodes, Greece.

Genus Eonapora Kozur and Mostler, 1979

Type species: Eonapora pulchra Kozur and Mostler, 1979 Eonapora pulchra Kozur and Mostler, 1979

Plate 3, fig. 8 


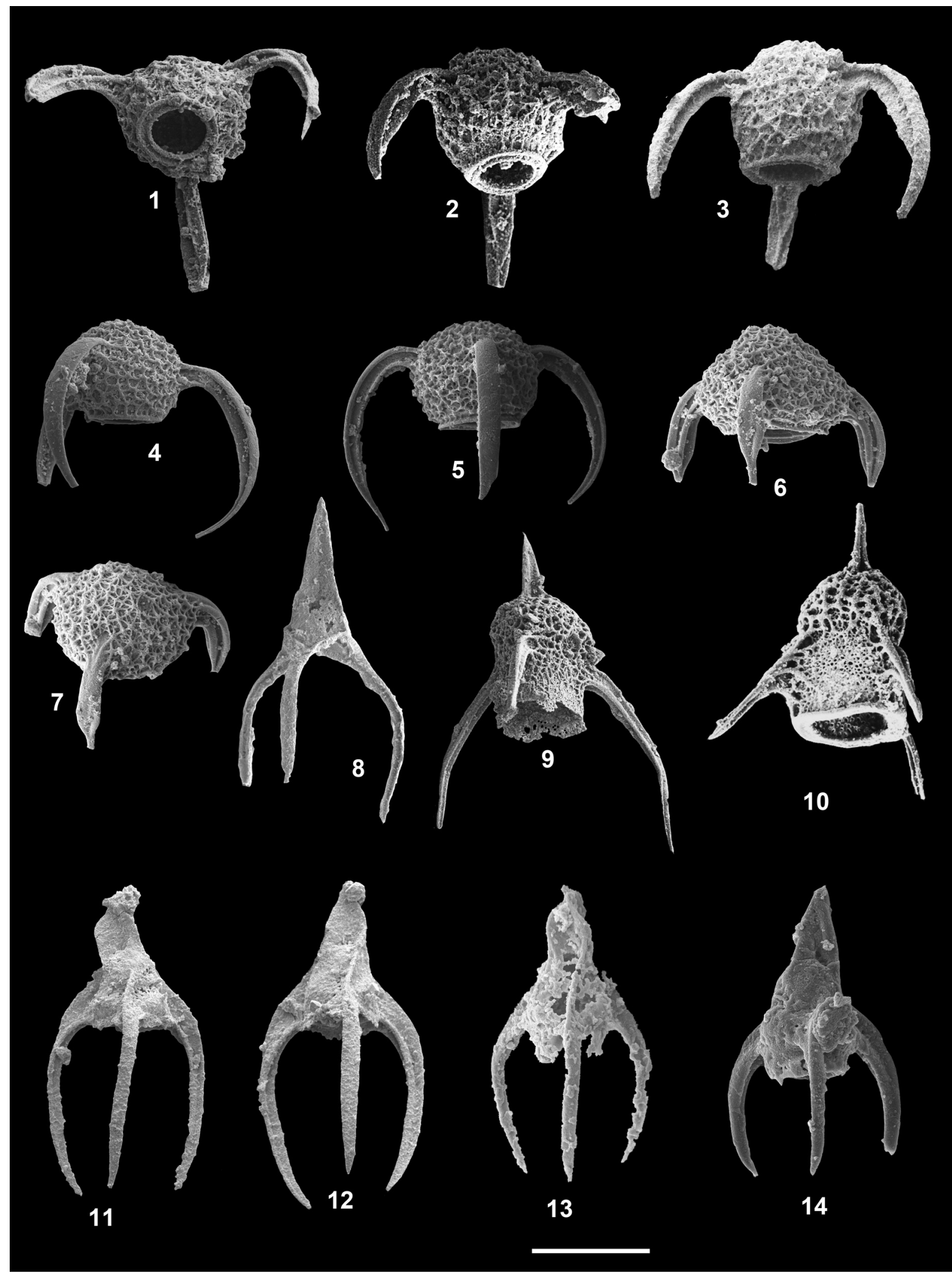

Plate 3. 1-5. Annulopoulpus parviaperturus (Kozur \& Mostler) (1-3. Sorgun Ophiolitic Mélange, Turkey; 4-5. Kopría Mélange, Rhodes, Greece) 6-7. Annulopoulpus gibber Ozsvárt, Dumitrica \& Hungerbuhler nov. sp. 8. Eonapora pulchra Kozur and Mostler, 1979 (Sorgun Ophiolitic Mélange, Turkey). 9. Annulohaeckeliella curvispina Ozsvárt, Dumitrica \& Hungerbuhler nov. sp. (Sorgun Ophiolitic Mélange, Turkey) 10. Annulohaeckeliella rectospina Ozsvárt, Dumitrica \& Hungerbuhler nov. sp. (Sosio valley, Sicily, Italy). 11-13. Tekinium bragini Ozsvárt, Dumitrica \& Hungerbuhler nov. sp. (11-12. Sorgun Ophiolitic Mélange, Turkey, 13. Kopría Mélange, Rhodes, Greece). 14. Tekinium robustum Ozsvárt, Dumitrica \& Hungerbuhler nov. sp. (Kopría Mélange, Rhodes, Greece). Scale bar $=100 \mu \mathrm{m}$.

Please cite this article in press as: Ozsvárt, P., et al., Mono- and dicyrtid Nassellaria (Radiolaria) from the Upper Carnian of the Sorgun Ophiolitic Mélange, Southern Turkey and Kopría Mélange, Rhodes, Greece. Revue de micropaléontologie (2016), http://dx.doi.org/10.1016/j.revmic.2016.11.004 
1979 Eonapora pulchra nov. sp. - Kozur and Mostler, p. 90, pl. 19, fig. 11.

Remarks: This species is very rare in our samples; we found it only in the Sorgun fauna. Except for its poorer preservation, the specimen illustrated resembles perfectly the holotype from the early Carnian of Austria.

Range and occurrence: Lower Carnian (upper Julian), Tetraporobrachia haeckeli Zone of Großreifling (Northern Calcareous Alps, Austria) and lower Tuvalian, Spongotortilispinus moixi Zone of the Sorgun Ophiolitic Mélange, Turkey.

Family Deflandrecyrtiidae Kozur and Mostler, 1979

Type genus: Deflandrecyrtium Kozur and Mostler, 1979

Genus Aropeon nov. gen.

Type species: Aropeon graecorus Ozsvárt, Dumitrica \& Hungerbuhler nov. sp.

Diagnosis: Skeleton dicyrtid, bell-shaped with a small cephalis armed with an apical horn. Initial spicule without D ray and with $\mathrm{V}$ ray extend outside into a small spine. Collar plate with 5 pores. Thorax bell-shaped, large, wide open, with flared distal part and bearing a peripheral girdle, at least in the two species herein described.

Remarks: Of the three species herein described we know the initial spicular structure only in one of them. However, since the external morphology of these species is rather similar we suppose that their initial structure is also similar. Generally the morphology of the species of this genus resembles the morphology of the genus Haeckelicyrtium Kozur and Mostler, 1979 from which it differs in having an apical horn and the initial spicule without D ray. Similar species as the ones described herein have been described by Tekin (1999) under the genus Deflandrecyrtium Kozur and Mostler, 1979. However, we interpret the genus Deflandrecyrtium as in De Wever et al. (2001) comprising dicyrtid nassellarians with D ray and skeleton more or less curved in dorsal direction. In this situation, we assign questionably the genus Aropeon to the family Deflandrecyrtiidae.

Etymology: Name formed by an arbitrary combination of letters. Masculine gender.

Range: Early Tuvalian to early Norian so far as known.

Aropeon cingulatus Ozsvárt, Dumitrica \& Hungerbuhler nov. sp.

Plate 4, figs. 1-2

Description: Test conical, hat-shaped with a flared, widely open distal part. Cephalis hemispherical and imperforate, bearing a conical spine of unknown length. Ventral ray well marked outside by a very short and multi-bladed spine from which radiate many ribs with very small pores in between. Primary lateral rays and probably the dorsal one marked outside by shallow depressions at the place of their connection to the shell. Thorax conical on proximal and middle part with numerous circular or oval pores somehow arranged in longitudinal rows on the upper part and in oblique rows on the lower part, their size increasing gradually in distal direction. Distal part strongly flared, practically coplanar consisting of an inner imperforate circular zone of and a peripheral circle of wide elongated pores. This circle of pores is closed at the periphery by a narrow circular ring below which is a broad vertical and imperforate girdle. The diameter of this girdle is smaller than the border of the circular ring that forms a kind of projecting roof above it.

Material: 3 specimens from the Kopría Mélange, Rhodes, Greece.

Holotype: The illustrated specimen in Pl. 4, figs. 1-2 (same specimen in two views), coll. MGL nr. 97935.

Dimensions (in $\mu \mathrm{m}$ based on 3 specimens): Height of cephalis 30-40, diameter thorax at base 160-185 diameter of thoracic skirt 310-410.

Remarks: As already remarked above the genus, although we do not know the structure of the initial skeleton, the morphological similarity with the species Aropeon graecorus nov. sp. suggests that it should be similar, without D ray.

Etymology: From the Latin cingulatus-having a belt.

Range and occurrence: Very rare in lower Tuvalian, Spongotortilispinus moixi Zone, Kopría Mélange, Rhodes, Greece.

Aropeon cinguloporatus Ozsvárt, Dumitrica \& Hungerbuhler nov. sp.

Plate 4, fig. 3

Description: Cephalis small, hemispherical and imperforate, bearing a long needle-shaped apical horn. Ventral spine very short, multi-bladed. Thorax bell-shaped with distal part strongly flared and distalmost border practically subvertical and perforate. Distal margin circular. The whole thorax has numerous circular or subcircular pores which are usually quincuncially arranged. Pores are very small on the upper part of thorax and increase suddenly in diameter distally. On the flared portion pores are usually irregularly or quincuncially arranged. Boundary between the porous flared portion and the vertical girdle abrupt. As in the other two species, but in this one more evident, pores increase rather quickly in size at the lower part of the conical portion and remain larger up to the border of shell.

Material: Two specimens from the Kopría Mélange, Rhodes, Greece.

Holotype: The illustrated specimen in P1. 4, fig. 3, coll. MGL nr. 97936.

Dimensions (in $\mu \mathrm{m}$ based on 2 specimens): Height of cephalis (without apical horn) 25-35, diameter of thorax at base 160-185, diameter of thoracic skirt 330-390.

Remarks: Although similar in shape with the other two new species of this genus, Aropeon cinguloporatus is morphologically closer to A. graecorus than to A. cingulatus by having the whole thorax perforated except the vertical distal belt.

Etymology: For having a porous distal belt.

Range and occurrence: Very rare in lower Tuvalian, Spongotortilispinus moixi Zone, Kopría Mélange, Rhodes, Greece.

Aropeon graecorus Ozsvárt, Dumitrica \& Hungerbuhler nov. sp.

Plate 4, figs. 4-6 


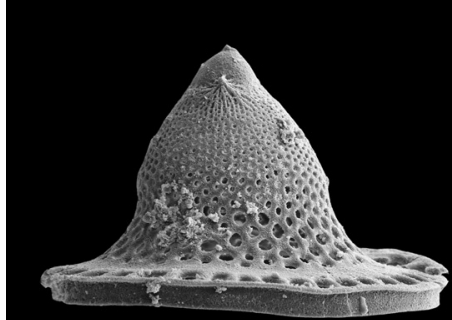

1
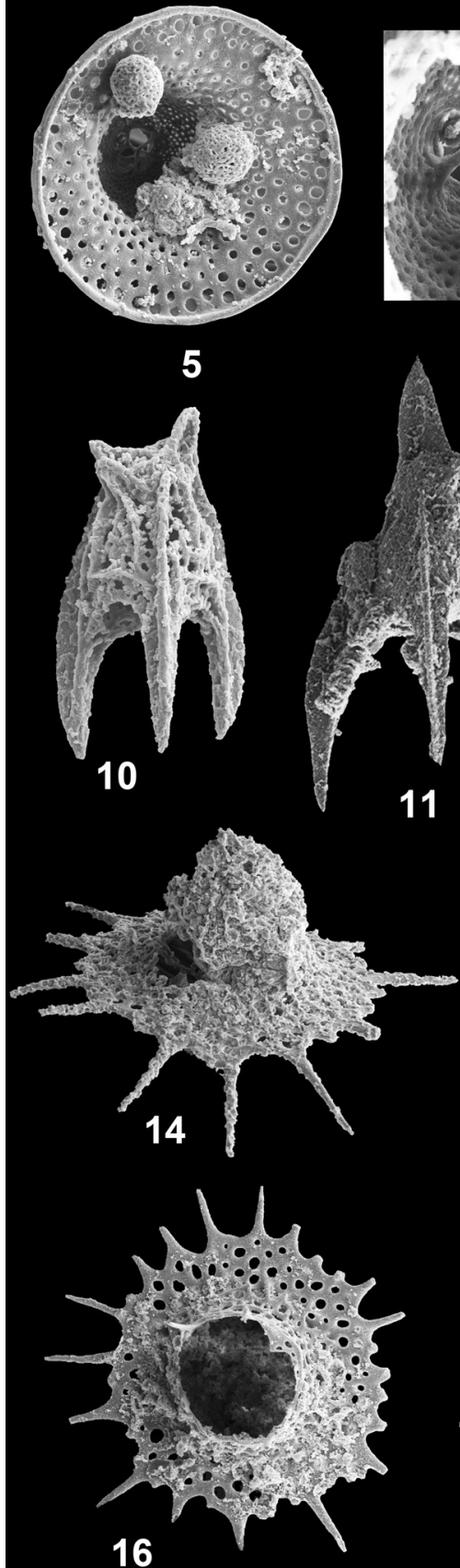

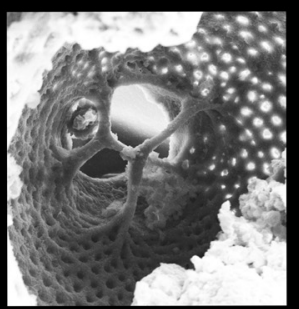

6

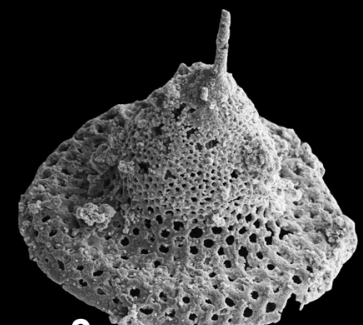

3

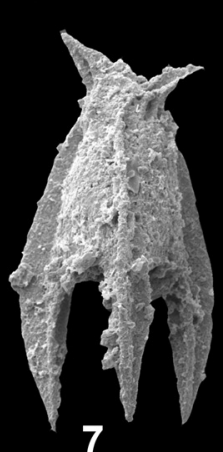

7

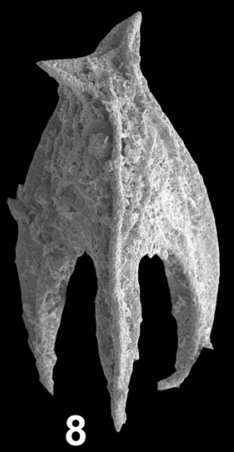

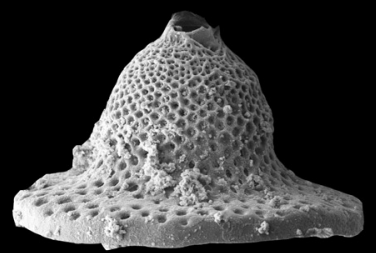

4
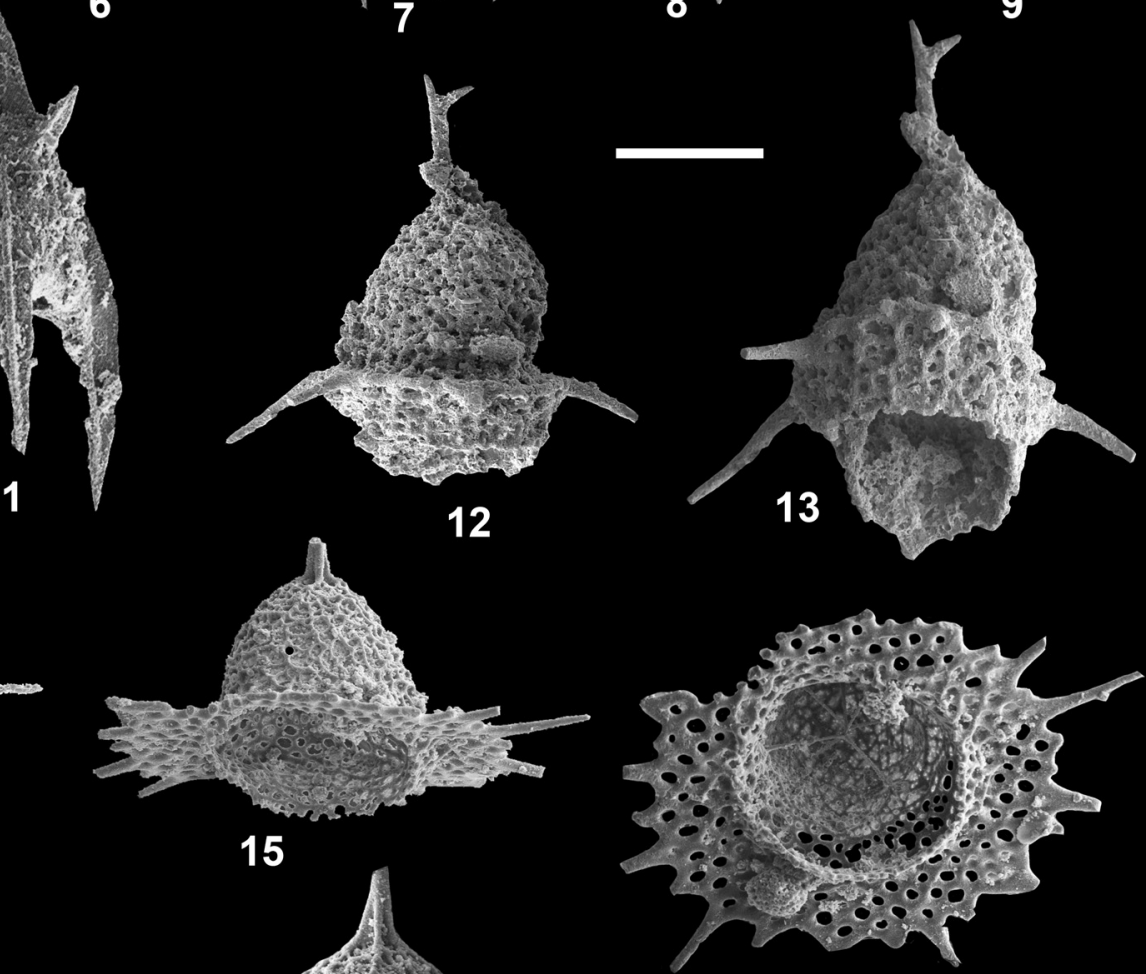

18
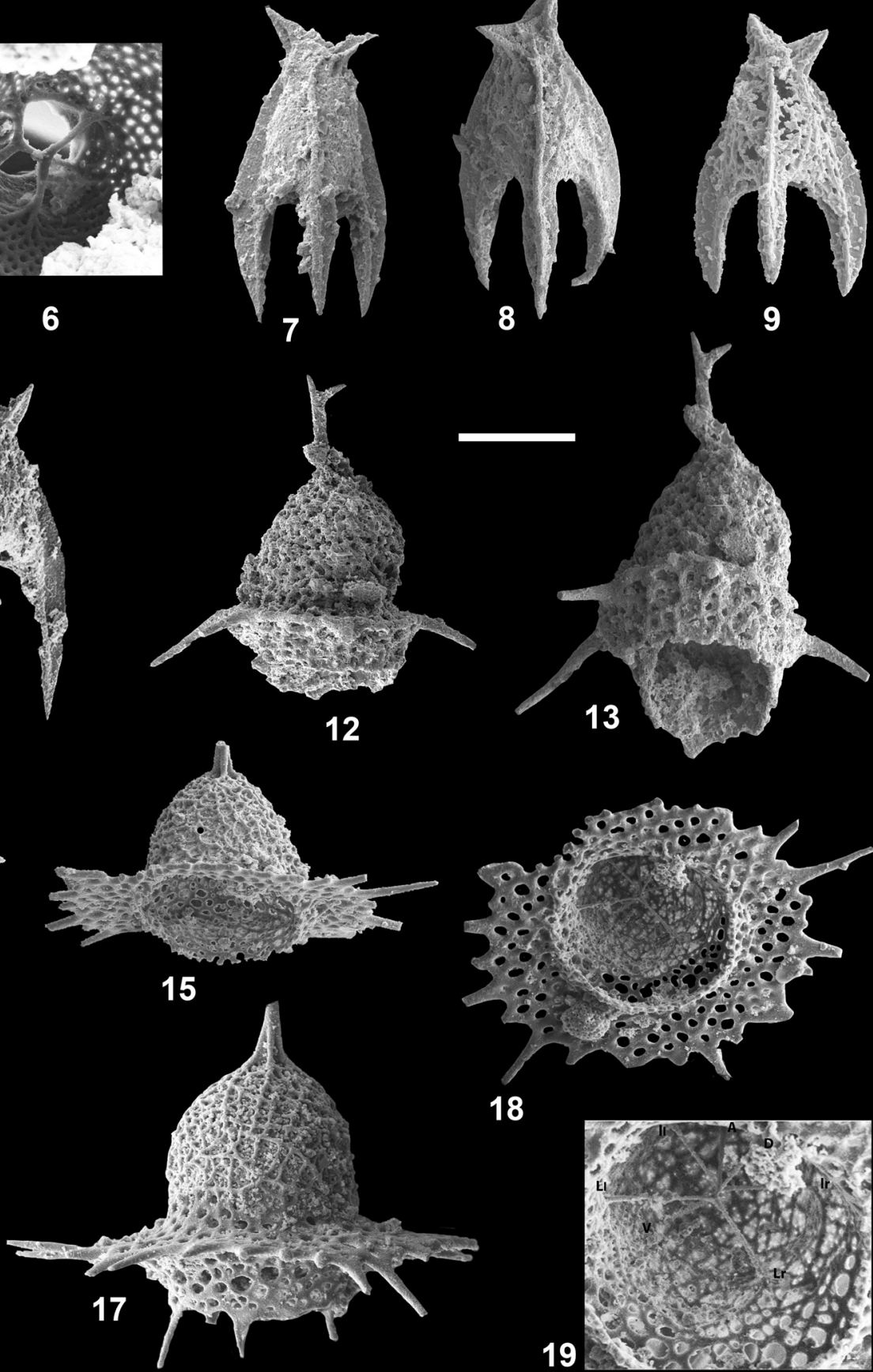

Plate 4. 1-2. Aropeon cingulatus Ozsvárt, Dumitrica \& Hungerbuhler nov. sp. (Kopría Mélange, Rhodes, Greece). 3. Aropeon cinguloporatus Ozsvárt, Dumitrica \& Hungerbuhler nov. sp. (Kopría Mélange, Rhodes, Greece). 4-6. Aropeon graecorus Ozsvárt, Dumitrica \& Hungerbuhler nov. sp. (Kopría Mélange, Rhodes, Greece). 7-10. Hinedorcus elegantissimus (Tekin) (Sorgun Ophiolitic Mélange, Turkey) 11. Hinedorcus robustus (Kozur \& Mostler) (Sorgun Ophiolitic Mélange, Turkey). 12-19. Nabolella thoraxaca Ozsvárt, Dumitrica \& Hungerbuhler nov. sp. (12-13. Sorgun Ophiolitic Mélange, Turkey 14-19. Kopría Mélange, Rhodes, Greece). Scale bar $=100 \mu \mathrm{m}$ (except fig. 6 whose scale bar $=25 \mu \mathrm{m})$.

Please cite this article in press as: Ozsvárt, P., et al., Mono- and dicyrtid Nassellaria (Radiolaria) from the Upper Carnian of the Sorgun Ophiolitic Mélange, Southern Turkey and Kopría Mélange, Rhodes, Greece. Revue de micropaléontologie (2016), http://dx.doi.org/10.1016/j.revmic.2016.11.004 
Description: Cephalis small, hemispherical and imperforate. Although the upper part of cephalis is broken off, the cephalis should bear a probably conical apical horn. Ventral spine very short, multi-bladed. Thorax bell-shaped with distal part strongly flared bordered by a vertical and imperforate belt. Except this belt thorax has numerous circular or subcircular pores which are usually quincuncially arranged and increase in diameter distally. On the flared portion pores are usually irregularly arranged. Boundary between the porous flared portion and the vertical girdle abrupt.

Material: 3 specimens from the Kopría Mélange, Rhodes, Greece.

Holotype: The illustrated specimen in Pl. 4, f. 4, coll. MGL nr. 97934.

Dimensions (in $\mu \mathrm{m}$ based on 3 specimens): Height of cephalis 32-38, diameter thorax at base 156-179, diameter of thoracic skirt 330-425.

Remarks: This new species differs from $A$. cingulatus nov. sp. by having pores on thorax more regularly arranged, by having the whole thorax perforated, without a distal circular imperforate zone and a distal circular row of large pores, and by not having a protecting roof at the boundary with the vertical distal belt. A closely related species (specimen) to A. graecorus is the paratype of the species Deflandrecyrtium pessagnoi Tekin (1999, pl. 30, fig. 13) from the early Norian (E. abneptis Conodont Zone) of Turkey. This specimen does not seem to belong to the same species as the holotype because the outline of the thorax and its pores are different, and the distal expanded part is much wider.

Etymology: From its occurrence in Greece.

Range and occurrence: Very rare in lower Tuvalian, Spongotortilispinus moixi Zone, Kopría Mélange, Rhodes, Greece.

\section{Genus Annulohaeckeliella Kozur and Mostler, 2006}

Type species: Annulohaeckeliella longipedis Kozur and Mostler, 2006

Range: Upper Fassanian (Longobardian) to lower Tuvalian so far as known.

Annulohaeckeliella curvispina Ozsvárt, Dumitrica \& Hungerbuhler nov. sp.

Plate 3, fig. 9

Description: Cephalis subglobular to hemispherical bearing a relatively long pointed pyramidal apical horn with thin blades and wide grooves. Cephalic wall double-layered, with an inner layer of very small pores and an outer layer of thick bars of various thickness forming triangular, quadrangular or oval pores. Thorax cylindrical, relatively short, with wall thinning distally due to the outer layer of cephalic pore frames that continues on the thorax and disappears gradually distally. Distal end of thorax without a ring. Feet threebladed, very long, pointing distally, downwardly directed and slightly curved. Feet free, without additional connections to the thorax.

Material: More than 50 specimens.

Holotype: The illustrated specimen in Pl. 3, fig. 9, NHMH, PAL 2016.22.
Dimensions (in $\mu \mathrm{m}$ based on 6 specimens): Height of cephalis 115-122, of apical horn 112-130, diameter of cephalis 120-130, length of feet $420-550$.

Remarks: This new species differs from A. rectospina nov. sp. in having the apical spine pyramidal and with thinner blades, feet much longer, slightly curved inward, and free, without connections with the tubular thorax, and in having the distal end of thorax very thin, without a thoracic ring.

Etymology: From the Latin curvus-curved and spina-spine.

Range and occurrence: Lower Tuvalian (Spongotortilispinus moixi Zone) of the Sorgun Ophiolitic Mélange, Turkey.

Annulohaeckeliella rectospina Ozsvárt, Dumitrica \& Hungerbuhler nov. sp.

Plate 3, fig. 10

Description: Cephalis globular bearing a straight, tricarinate apical horn with thick blades and very narrow grooves. It has two layers of meshwork, an inner layer of very small pores and an outer layer with thick pore frames of variable thickness forming larger oval or triangular pores of variable shape and size with small nodes at vertices of pore frames. Thorax slightly longer than cephalis, cylindrical and terminated in a distal imperforated ring. It is thin-walled consisting of a single layer with very small circular and irregularly arranged pores. This wall is the continuation of the inner layer of the cephalis. Feet straight, pointed, slightly longer than thorax and threebladed, arising from the base of cephalis and connected with thorax on most part of its length through many obliquely directed bars.

Material: More than 5 specimens.

Holotype: The illustrated specimen in Pl. 3, f. 10, HNHM, PAL 2016.23

Dimensions (in $\mu \mathrm{m}$ based on 3 specimens): Height of cephalis 110-120, of apical horn 100-110, diameter of cephalis 120-130, length of feet 225-250.

Remarks: However, this species is also present in the Sorgun material, its preservation is not so perfect than the illustrated specimen from Sosio valley, Sicily, Italy. Therefore, we have chosen this specimen as holotype of A. rectospina nov. sp. This new species resembles the upper Ladinian species Annulohaeckeliella longipedis Kozur \& Mostler and A. pulchra Kozur \& Mostler in having thorax terminated in a ring and feet straight and closely connected to the thoracic wall by a series of bars. However it differs essentially from them in not having bladed and twisted apical horn. A. rectospina $\mathrm{n}$. sp. is compared with A. curvispina $\mathrm{n}$. sp. under the latter species.

Etymology: From the Latin rectus-straight and spina-spine.

Range and occurrence: Lower Julian from Sosio valley, Sicily, Italy; lower Tuvalian, Sorgun Ophiolitic Mélange, Turkey.

Family Ultranaporidae Pessagno 1977

Genus Hinedorcus Dumitrica, Kozur \& Mostler, 1980

syn. Picapora Kozur and Mostler, 1981

Type species: Hinedorcus alatus Dumitrica, Kozur \& Mostler, 1980 
Hinedorcus elegantissimus (Tekin, 1999)

Pl. 4, figs. 7-10

1999 Picapora elegantissima nov. sp. - Tekin, p. 147, pl. 32, figs. 7, 11

2007 Picapora robusta Kozur \& Mostler - Bragin, p. 1005, pl. 12, fig. 10

Remarks: The specimens from the Sorgun Ophiolitic Mélange, Turkey have a more dumpy test with smaller apical and ventral horn and wear smaller feet than the holotype (Tekin, 1999).

Range and occurrence: Lower Tuvalian (Spongotortilispinus moixi Zone) of the Sorgun Ophiolitic Mélange, Turkey, to lower Norian from the Yaylakuzdere Measured section, Alakircay Nappe, Antalya Nappes, Kemer, Antalya, Turkey, and Mamonia Complex, southwestern Cyprus.

\section{Hinedorcus robustus (Kozur and Mostler, 1981)}

Pl. 4, fig. 11

1981 Picapora robusta nov. sp. - Kozur and Mostler, p. 110, pl. 7, figs. 1, 2.

1999 Picapora robusta Kozur \& Mostler - Tekin, p. 147, pl. 32, figs. 8, 9 .

Remarks: The illustrated specimen from the Sorgun Ophiolitic Mélange, Turkey, has a bit sharper apical horn than the holotype of the species, and the feet are more divergent.

Range and occurrence: Middle Julian of Göstling and Großreifling (Northern Calcareous Alps, Austria) to lower Tuvalian (Spongotortilispinus moixi Zone) of the Sorgun Ophiolitic Mélange, Huğlu Unit, Beyşehir-Hoyran Nappe, Bozkir, Konya, Turkey.

Genus Tekinium Ozsvárt, Dumitrica \& Hungerbuhler nov. gen.

Type species: Sanfilippoella lengeranlii Tekin, 1999.

Diagnosis: Test dicyrtid with a well-developed, three-bladed apical horn and 3 tri-bladed feet. Cephalis small, globular, usually imperforate with initial spicule comprising $\mathrm{MB}, \mathrm{A}$, V, D, 2L and 21. Dorsal and primary lateral rays extended into three-bladed feet, ventral spine very short and pyramidal, and secondary rays not expressed outside. Thorax larger than cephalis, perforate and open distally. The third segment, when developed, is velum-like, thin, cylindrical and usually preserved as remains at the base of thorax.

Remarks: The type species was erroneously assigned to Sanfilippoella Kozur and Mostler 1979. As Kozur and Mostler (1994) remarked, Sanfilippoella is a dicyrtid with a large cephalis that can be globular or conical and perforated, and thorax is regarded structurally as a velum. We include in this new genus Sanfilippoella lengeranlii Tekin, Tekinium bragini nov. sp., both very closely related species, and Tekinium robustum nov. sp.

Etymology. The genus is named for Dr. Ugur Kagan Tekin, who first illustrated the type species, for his outstanding contribution to the knowledge of Mesozoic radiolarians.

Range and occurrence: Upper Carnian to lower Norian, Turkey and Cyprus, so far as known.
Tekinium bragini Ozsvárt, Dumitrica \& Hungerbuhler nov. sp.

Plate 3, figs. 11-13

Description: Cephalis globular imperforate with a broad tricarinate apical horn with thin and broad blades and pointed tip. Blades may extend obliquely along cephalic and thoracic wall and continue on the three feet where they form their external blades. Thorax short but much wider than cephalis with 3 dome-shaped lobes developed in the 3 intercostal areas. It is perforated by many small pores and its boundary with abdomen is marked by a constriction. Following segment is velum shaped but very short in our specimens due to the poor preservation, but its presence is marked by some lamellar remains. Feet very long, downwardly directed, pointing distally and curved, converging so that their distal ends tend to near.

Material: More than 100 specimens.

Holotype: The illustrated specimen in Pl. 3, fig. 12, NHMH, PAL 2016.24.1

Dimensions (in $\mu \mathrm{m}$ based on 9 specimens): Height of cephalis (with apical horn) 125-139, diameter of cephalis 74-80, length of feet: 148-187.

Remarks: The proximal part of this species resembles the respective part of the younger species Sanfilippoella lengeranlii Tekin illustrated by both Tekin (1999) and Bragin (2007) from which it differs by having very long, downwardly directed and curved feet. One of the specimens illustrated by Bragin (2007, pl. 12, fig. 4) as S. lengeranlii seems to be well comparable to the Longobardian species Annulohaeckeliella longipedis Kozur and Mostler, 2006, because no small cephalis at the base of apical horn is visible and because it has a long distal segment terminated in a ring. The specimens from the Sorgun Ophiolitic Mélange, Turkey, and Kopría Mélange, Rhodes, differ from the type species of the genus by having much longer and converging feet.

Etymology: The species is name for Dr. Nikita Yu. Bragin, Moscow, for his contribution to the knowledge of Triassic and Jurassic radiolarians.

Range and occurrence: Lower Tuvalian (Spongotortilispinus moixi Zone) of the Sorgun Ophiolitic Mélange, Turkey, and Kopría Mélange, Rhodes, Greece.

Tekinium robustum Ozsvárt, Dumitrica \& Hungerbuhler nov. sp.

Plate 3, fig. 14

Description: Test dicyrtid with a robust three-bladed, pointed and slightly sinistrally twisted apical horn. Blades of horn broad at base. Cephalis globular, practically imperforated except for a few tiny pores at the base of ventral spine, which is pyramidal, three-bladed and very small. Collar constriction well visible. Thorax sensibly larger than cephalis, especially on the proximal part, with which it forms a bell-shaped body. Wall of thorax perforated by rare and very small pores. Distal part wide open, cylindrical. Feet arched, three-bladed on the proximal half with one blade external and two lateral, and conical on the distal half.

Material: Two specimens from Kopría Kopría Mélange, Rhodes, Greece. 
Holotype: The illustrated specimen in P1. 3, fig. 14, coll. MGL nr. 97937.

Dimensions (in $\mu \mathrm{m}$ based on 2 specimens): Height of cephalis (with apical horn) 107-115, diameter of cephalis 45-55, length of feet 90-120.

Remarks: Tekinium robustum is well distinguished from T. bragini nov. sp. in having a more robust apical spine, non lobated thorax and shorter feet. It resembles somehow the holotype of T. lengeranlii (Tekin) from which it differs in having another type of twisting of the apical spine, cephalis better distinguished from thorax, curved feet and a much shorter cylindrical distal segment.

Etymology. From the Latin robustus, - $a$, -um-robust.

Range and occurrence: Very rare in Kopría Mélange, Rhodes, Greece.

Family Nabolellidae (Kozur and Mostler, 1979)

syn.: Fueloepicyrtidae Kozur and Mostler, 1981

Genus Nabolella Petrushevskaya, 1981

\section{Hom.: Squinabolella Kozur and Mostler, 1979}

Type species: Nabolella longispinosa (Kozur and Mostler, 1979)

Remarks: The position of the initial spicule would suggest that the genus Nabolella could be also considered a dicyrtid with no collar segmentation as the genus Caponabolella nov. gen. The shell wall with its double-layered structure and the reticulate structure of the outer layer are also characters in common of both genera.

Range: Middle Julian to lower Tuvalian.

Nabolella thoraxaca Ozsvárt, Dumitrica \& Hungerbuhler nov. sp.

Plate 4, figs. 12-19

Description: Cephalis large, bell-shaped with dome-shaped apical part and cylindrical lateral sides. Spicule as with the genus, thin, situated at the upper part of cephalis. No spicule rays are extended outside except the apical one. Apical horn long, four-bladed and pyramidal proximally, cylindrical distally and pointed. Wall of cephalis two layered, with an inner layer made of circular to oval pores and an outer layer made of polygonal, usually quadrangular or triangular areas within which there are very small pores. These areas result from a network of differently directed crests that intersect, and that developed very small nodes at the nodal points of the network. Distal part of cephalis strongly expanded laterally forming a circumferential plate of variable diameter with circular to oval pores and numerous spines of various length, most of them coplanar. Thorax shorter than cephalis, cylindrical, of the same diameter as cephalis and widely open. It consists of a single layer wall with numerous circular or oval pores of various arrangements. Distal end prolonged into several conical spines of various lengths.

Material: Three specimens in Kopría Mélange, Rhodes, Greece, and more than 10 specimens in the Sorgun Mélange, Turkey.
Holotype: The specimen in Pl. 4, fig. 17, coll. MGL nr. 97938.

Dimensions (in $\mu \mathrm{m}$ based on 9 specimens): Height of cephalis (without apical horn) 115-127, apical horn 95-110, diameter of cephalis 195-210, height of thorax 100-120, diameter of thorax at base 80-100.

Remarks: This new species differs from N. longispinosa (Kozur and Mostler, 1979) in having a well-developed cephalic skirt, spines of various lengths, border of skirt not thickened, and a well-developed thorax. The difference between the specimen from the Sorgun Mélange and those from the Kopría Mélange is interpreted as variation within the species. The presence of a well-developed thorax seems to be characteristic of this species, since the three species Kozur and Mostler $(1979,1981)$ described from the upper Julian either have no thorax or it is just sketched.

Etymology: For having a well-developed thorax.

Range and occurrence: Lower Tuvalian (Spongotortilispinus moixi Zone) from the Kopría Mélange, Rhodes, Greece, and Sorgun Mélange, Turkey.

Genus Caponabolella Ozsvárt, Dumitrica \& Hungerbuhler nov. gen.

Type species: Caponabolella longispinosa Ozsvárt, Dumitrica \& Hungerbuhler nov. sp.

Diagnosis: Test cone-shaped, dicyrtid without apical horn. Cephalis hemispherical with complete spicular system (MB, A, 2L, 2l, D, V). Spicule centre (MB) at the base of cephalis. Collar boundary marked by a weak external constriction, which corresponds internally with the arches Ll, Dl and partly LV. Rays $\mathrm{D}$ and $\mathrm{L}$ may be prolonged along the thorax and beyond its distal end into spines. Thorax gradually widening, lacking thoracic skirt; oral opening circular, constricted, with thickened ring. Spines present or absent around distal edge of thorax.

Remarks: This genus differs from Nabolella Petrushevkaya, 1981 by lacking the apical horn, thoracic skirt and by the presence of a terminal thickened ring around the oral opening. It is, however, very close to this genus in having no collar plate at the base of cephalis, the rays of the initial spicule being rather free inside shell cavity.

Etymology: In allusion to its similarity to the genus Nabolella Petrushevskaya and the hat-shaped test.

Range and occurrence: Lower Tuvalian (Spongotortilispinus moixi Zone) of the Sorgun Ophiolitic Mélange, Turkey.

Caponabolella longispinosa Ozsvárt, Dumitrica \& Hungerbuhler nov. sp.

Plate 5, figs. 1-5

Description: Test cone-shaped, dicyrtid. Cephalis hemispherical to globular without apical horn. Thorax cone-shaped, widening gradually and separated from cephalis by a collar constriction. Meshwork of cephalis and thorax double-layered. Outer layer consists of circular to polygonal pore frames and inner layer is smooth perforated by circular pores. Base of thorax composed of same meshwork as that of cephalis and thorax; it is armed with 5-7 spines, three of which being prolongation of rays $\mathrm{D}$ and $2 \mathrm{~L}$. Oral opening large, circular with a thick, smooth ring. 


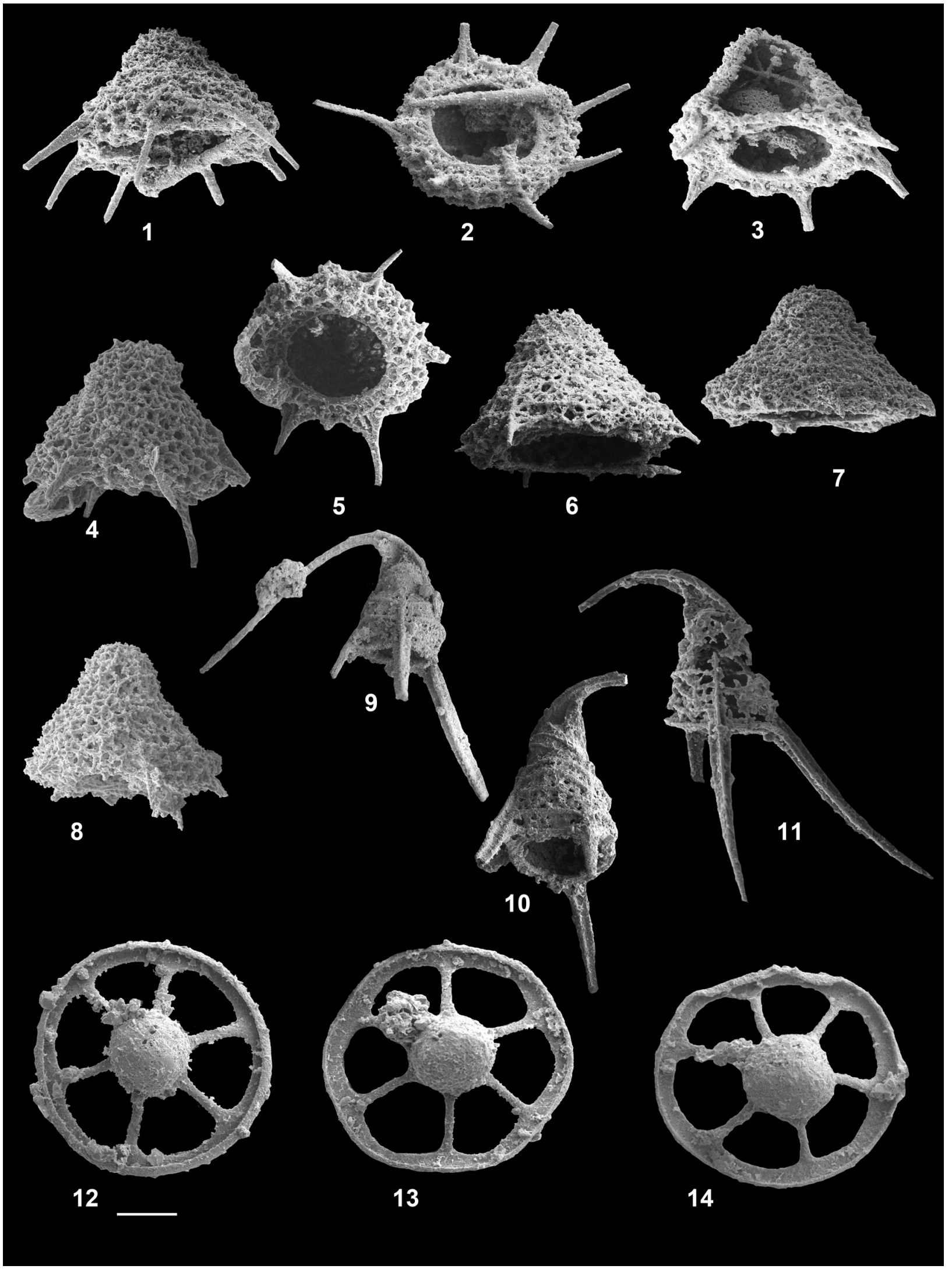

Plate 5. 1-5. Caponabolella longispinosa Ozsvárt, Dumitrica \& Hungerbuhler nov. sp. (1-3. Sorgun Ophiolitic Mélange, Turkey; 4-5. Kopría Mélange, Rhodes, Greece) 6-8. Caponabolella brevispinosa Ozsvárt, Dumitrica \& Hungerbuhler nov. sp. (6-7. Sorgun Ophiolitic Mélange, Turkey 8. Kopría Mélange, Rhodes, Greece). 9-11. Silicarmiger longospinosus Ozsvárt, Dumitrica \& Hungerbuhler nov. sp. (9-10. Sorgun Ophiolitic Mélange, Turkey; 11. Kopría Mélange, Rhodes, Greece). 12-14. Pseudosaturniforma carnica Kozur and Mostler (Sorgun Ophiolitic Mélange, Turkey). Scale bar $=100 \mu \mathrm{m}$.

Please cite this article in press as: Ozsvárt, P., et al., Mono- and dicyrtid Nassellaria (Radiolaria) from the Upper Carnian of the Sorgun Ophiolitic Mélange, Southern Turkey and Kopría Mélange, Rhodes, Greece. Revue de micropaléontologie (2016), http://dx.doi.org/10.1016/j.revmic.2016.11.004 
Material: More than 50 specimens.

Holotype: The specimen in pl. 5, figs. 1-2 (same specimen in two different views), HNHM, PAL 2016.26.1

Dimensions (in $\mu \mathrm{m}$ based on 7 specimens): Height of cephalis: 50-65, diameter of cephalis 60-75, height of thorax 73-85, diameter of thorax at base 200-225.

Remarks: Caponabolella longispinosa nov. sp. differs from C. brevispinosa nov. sp. by having longer spines around the distal end of thorax.

Etymology: In allusion to its long spines around the distal part of thorax.

Range and occurrence: Lower Tuvalian (Spongotortilispinus moixi Zone) of the Sorgun Ophiolitic Mélange, Turkey; Kopría Mélange, Rhodes, Greece.

Caponabolella brevispinosa Ozsvárt, Dumitrica \& Hungerbuhler nov. sp.

Plate 5, figs. 6-8

Description: Test dicyrtid, conical or hat-shaped; cephalis hemispherical without apical horn. Thorax gradually expanding. Meshwork of cephalis and thorax double-layered, outer layer consisting of circular to polygonal pore frames and the inner layer consisting of polygonal to circular pores. Oral opening slightly constricted, circular with a smooth ring; the widest distal part of thorax with 4-5 small, pointed spines, three of which are prolongation of $\mathrm{D}$ and $2 \mathrm{~L}$.

Material: More than 10 specimens.

Holotype: The specimen in Pl. 5, fig. 6, NHMH, PAL 2016.27.1

Dimensions (in $\mu \mathrm{m}$ based on 5 specimens): Height of cephalis 55-68, diameter of cephalis 62-78, height of thorax 73-85, diameter of thorax at base 198-225.

Remarks: Caponabolella brevispinosa nov. sp. differs from C. longispinosa nov. sp. by having significantly smaller and fewer spines around the distal end of thorax, and collar constriction less marked.

Etymology: In allusion to its short and rare spines around the distal part of thorax.

Range and occurrence: Lower Tuvalian (Spongotortilispinus moixi Zone) of the Sorgun Ophiolitic Mélange, Turkey, and Kopría Mélange, Rhodes, Greece.

Family Silicarmigeridae Kozur \& Mostler, 1980

Genus Silicarmiger Dumitrica, Kozur \& Mostler, 1980

Type specie: Silicarmiger costatus Dumitrica, Kozur \& Mostler, 1980

Silicarmiger longospinosus Ozsvárt, Dumitrica \& Hungerbuhler nov. sp.

Plate 5, figs. 9-11

aff. 1984 Silicarmiger curvatus (Kozur \& Mostler) - Kozur, p. 63 , pl. 4 , fig. 3 .

aff. 1994 Silicarmiger curvatus (Kozur \& Mostler) - Kozur and Mostler, p. 119, pl. 33, figs. 11, 12, 14.

aff. 1999 Silicarmiger curvatus (Kozur \& Mostler) - Tekin, p. 162, pl. 38, figs. 12, 13 .
2007 Silicarmiger curvatus (Kozur \& Mostler) - Tekin and Bedi, p. 178, pl. 2, figs. 7, 8 .

Description: Shell conical, dicyrtid as the genus. Thorax conical increasing in diameter constantly and divided externally into segments by $2-4$ or possibly more high circumferential ridges. Cephalis well distinguished from thorax, globular, with ribbed surface and perforated by a variable number of pores. Apical horn broad proximally, with a broad triangular blade on the ventral side that disappears quickly on the curved portion of the spine. Horn strongly curved downwardly in ventral direction and very long, thin and circular in cross-section, and slightly curved outwardly on the terminal part. Feet also very long, pointed, three-bladed, divergent and slightly curved outwardly on the distal half.

Material: More than 10 specimens.

Holotype: The specimen in Pl. 5, fig. 9, HNHM, PAL 2016.28.2.

Dimensions (in $\mu \mathrm{m}$ based on 6 specimens): Height of cephalis (without apical horn) 50-65, length of apical horn 213-250, diameter of cephalis 55-72, height of thorax 60-78, diameter of thorax at base 83-98.

Remarks: This new species has been usually erroneously determined as Silicarmiger curvatus (Kozur and Mostler, $1979 \mathrm{~b}$ from the lower Julian from Göstling, Austria, originally described as Eonapora curvata and poorly illustrated under binocular. This Austrian species does not seem at all to be a Silicarmiger species because it shows no segmented postcephalic body. The only species that seems somehow to belong to this new species is that illustrated by Tekin and Bedi (2007a) from the Köseyahya Nappe near Elbistan, but its spines are not yet so long as this species from the Moixi Zone. The upper Julian species from Elbistan seems to be, in fact, the forerunner of the present one. Possibly the specimens from the Moixi Zone and those from Haeckeli Zone are subspecies of the species S. longospinosus nov. sp.

Range and occurrence: Lower Julian from Sosio valley, Sicily, Italy, Upper Julian, Tetraporobrachia haeckeli Zone, from the Köseyahya Nappe, Elbistan, Turkey, to lower Tuvalian, Spongotortilispinus moixi Zone, from the Sorgun Ophiolitic Mélange, Turkey, and Kopría Mélange, Rhodes, Greece.

Family Pseudosaturniformidae Kozur and Mostler, 1979

Genus Pseudosaturniforma Kozur and Mostler, 1979 emend. Blome, 1984

Type species: Pseudosaturniforma latimarginata Kozur and Mostler, 1979

Pseudosaturniforma carnica Kozur and Mostler, 1979

Plate 5, figs. 12-14

1979 Pseudosaturniforma carnica nov. sp. - Kozur and Mostler, p. 92, pl. 17, fig. 3.

1981 Pseudosaturniforma carnica Kozur \& Mostler - Kozur and Mostler, pl. 22, fig. 3.

1984 Pseudosaturniforma carnica Kozur \& Mostler - Blome, p. 318 , pl. 13, figs. 5, 9, 11, 18. 
1999 Pseudosaturniforma carnica Kozur \& Mostler - Bragin and Krylov, p. 558, figs. 10I, K, L.

1999 Pseudosaturniforma carnica Kozur \& Mostler - Tekin, p. 156, pl. 34, figs. 7-10.

Remarks: Cephalis relatively small, circular in outline with tiny pores. Shape of thoracic ring ranges from circular (pl. 5, fig. 12) to hexagonal (pl. 5, fig. 13) in outline in our material. The specimen in pl. 5, fig. 14 shows some malformations or regenerations of the edge of the ring.

Range and occurrence: Lower Carnian (lower to middle Julian) of Göstling and Großreifling (Northern Calcareous Alps, Austria); Carnian? - Norian (lower to upper middle) of Oregon, USA, lower Tuvalian (Spongotortilispinus moixi Zone) of the Sorgun Ophiolitic Mélange, Turkey and lower Norian from the Yaylakuzdere section, Alakircay Nappe, Antalya Nappes, Kemer, Antalya, Turkey.

\section{Disclosure of interest}

The authors declare that they have no competing interest.

\section{Acknowledgements}

This paper is dedicated to the memory of Heinz W. Kozur, who was an outstanding expert on radiolarians, conodonts, ostracods, conchostracans and on the Triassic System in general. We are very grateful to Dr. Nikita Bragin and an anonymous reviewer for their helpful reviews. This is MTA-MTM-ELTE Paleo Contribution No. 222.

\section{References}

Blome, C., 1984. Upper Triassic Radiolaria and radiolarian zonation from western North America. Bulletins of American Paleontology 85 (318), 1-88.

Bragin, N.Y., 2007. Late Triassic radiolarians of southern Cyprus. Paleontological Journal 41, 951-1029.

Bragin, N.Y., Krylov, K.A., 1999. Early Norian Radiolaria from Cyprus. Geodiversitas 21, 539-569.

De Wever, P., 1982. Radiolaires du Trias et du Lias de la Tethys (Systématique, Stratigraphie). Société Géologique du Nord, Publication 7, 1-599.

De Wever, P., 1984. Triassic Radiolarians from the Darno Area (Hungary). Acta Geologica Hungarica 27, 295-306.

De Wever, P., Dumitrica, P., Caulet, J.P., Caridroit, M., 2001. Radiolarians in the sedimentary record. Gordon and Breach Science Publishers, Amsterdam, $533 \mathrm{pp}$.

De Wever, P., O’Dogherty, L., Caridroit, M., Dumitrica, P., Guex, J., Nigrini, C., Caulet, J.P., 2003. Diversity of radiolarian families through time. Bulletin de la Société Géologique de France, Série VIII 174, 453-469.

De Wever, P., Sanfilippo, A., Riedel, W.R., Gruber, B., 1979. Triassic radiolarians from Greece, Sicily and Turkey. Micropaleontology 25, 75-110.

Dumitrica, P., Kozur, H., Mostler, H., 1980. Contribution to the radiolarian fauna of the Middle Triassic of the Southern Alps. Geologisch Paläontologische Mitteilungen Innsbruck 10, 1-46.

Dumitrica, P., Tekin, K.U., Bedi, Y., 2013b. Taxonomic study of spongy spumellarian Radiolaria with three and four coplanar spines or arms from the middle Carnian (Late Triassic) of the Köseyahya nappe (Elbistan, SE Turkey) and other Triassic localities. Paläontologische Zeitschrift 87, 345-396.

Dumitrica, P., Tekin, U.K., Bedi, Y., 2010. Eptingiacea and Saturnaliacea (Radiolaria) from the middle Carnian of Turkey and some late Ladinian to early Norian samples from Oman and Alaska. Paläontologische Zeitschrift 84, 259-292.
Dumitrica, P., Tekin, U.K., Bedi, Y., 2013a. Taxonomic study of the tetrahedral, pentagonal and hexagonal spongy spumellarian Radiolaria from the middle Carnian (Late Triassic) of the Köseyahya nappe (Elbistan, SE Turkey) and other Triassic localities. Paläontologische Zeitschrift 87, 311-344.

Dumitrica, P., Hungerbühler, A., 2007. Blechschmidtia n. gen. et Tjerkium n. gen., un cas de gradualisme phylétique des Radiolaires Saturnalides du Trias. Bulletin de la Société vaudoise des Sciences naturelles 90, 217-243.

Gawlick, H.-J., Goričan, Š., Missoni, S., Dumitrica, P., Lein, R., Frish, W., Hoxha, L., 2016. Middle and Upper Triassic radiolarite components from the Kcira-Dushi-Komani ophiolitic mélange and their provenance (Mirdita Zone, Albania). Revue de Micropaléontologie 59, 359-380.

Koepke, J., Seidel, E., Kreuzer, H., 2002. Ophiolites on the Southern Aegean islands Crete, Karpathos and Rhodes: composition, geochronology and position within the ophiolite belts of the Eastern Mediterranean. Lithos 65, 183-203.

Kozur, H., 1984. New radiolarian taxa from the Triassic and Jurassic. Geologisch Paläontologische Mitteilungen Innsbruck 13, 49-88.

Kozur, H., Mostler, H., 1972. Beiträge zur Erforschung der mesozoischen Radiolarien. Teil I: Revision der Oberfamilie Coccodiscacea HAECKEL 1862 emend. und Beschreibung ihrer triassischen Vertreter. Geologisch Paläontologische Mitteilungen Innsbruck 2, 1-60.

Kozur, H., Mostler, H., 1978. Beiträge zur Erforschung der mesozoischen Radiolarien Teil II: Oberfamilie Trematodiscacea HAECKEL 1862 emend. und Beschreibung ihrer triassischen Vertreter. Geologisch Paläontologische Mitteilungen Innsbruck 8, 123-182.

Kozur, H., Mostler, H., 1979. Beiträge zur Erforschung der mesozoischen Radiolarien. Teil III: Die Oberfamilien Actinommacea HAECKEL 1862 emend., Artiscacea HAECKEL1882, Multiarcusellacea nov. der Spumellaria und triassische Nassellaria. Geologisch Paläontologische Mitteilungen Innsbruck 9, 1-132.

Kozur, H., Mostler, H., 1981. Beiträge zur Erforschung der mesozoischen Radiolarien. Teil IV: Thalassosphaeracea HAECKEL, 1862, Hexastylacea HAECKEL, 1862 emend. PETRUŠEVSKAJA, 1979, Sponguracea HAECKEL, 1862 emend. und weitere triassische Lithocycliacea, Trematodiscacea, Actinommacea und Nassellaria. Geologisch Paläontologische Mitteilungen Innsbruck, Sonderband 1, 1-208.

Kozur, H., Mostler, H., 1994. Anisian to middle Carnian radiolarian zonation and description of some stratigraphically important radiolarians. Geologisch Paläontologische Mitteilungen Innsbruck, Sonderband 3, 39-255.

Kozur, H., Mostler, H., 2006. Radiolarien aus dem Longobard der Dinariden. Hallesches Jahrbuch für Geowissenschaften 28, 23-91.

Kozur, H.W., Moix, P., Ozsvárt, P., 2007a. Characteristic Nassellaria of the lower Tuvalian (Upper Triassic) Spongotortilispinus moixi Zone of the Huğlu Unit in the Mersin Mélange, southeastern Turkey. Bulletin de la Société vaudoise des Sciences naturelles 90, 151-173.

Kozur, H.W., Moix, P., Ozsvárt, P., 2007b. Further new Nassellaria of the lower Tuvalian (Upper Triassic) Spongotortilispinus moixi Zone of the Huğlu Unit in the Mersin Mélange. Bulletin de la Société vaudoise des Sciences naturelles 90, 197-215.

Kozur, H.W., Moix, P., Ozsvárt, P., 2007c. Stratigraphically important Spumellaria and Entactinaria from the lower Tuvalian (Upper Triassic) of the Huğlu Unit in the Mersin Mélange, southeastern Turkey. Bulletin de la Société vaudoise des Sciences naturelles 90, 175-195.

Kozur, H.W., Moix, P., Ozsvárt, P., 2009. New Spumellaria (Radiolaria) from the Early Tuvalian Spongotortilispinus moixi Zone of Southeastern Turkey, with some remarks on the age of this fauna. Jahrbuch der geologischen Bundesanstalt, Wien 149, 25-59.

Lahm, B., 1984. Spumellarienfaunen (Radiolaria) aus den mitteltriassischen Buchensteiner-Schichten von Recoaro (Norditalien) und den obertriassischen Reiflingerkalken von Grosreifling (Österreich). Systematik, Stratigraphie. Münchner geowissenschaftliche Abhandlungen, Reihe A. Geologie und Paläontologie 1, 1-161.

Lekkas, E., Danamos, G., Skourtsos, E., Sakellariou, D., 2002. Position of the Middle Triassic Tyros beds in the Gavrovo-Tripolis unit (Rhodes island, Dodecanese, Greece). Geologica Carpathica 53, 3744.

Masset, O., Moix, P., 2004. Les mélanges de l'ophiolite de Mersin (Turquie du Sud). Lausanne, pp. 1-143 (Unpublished MSc. thesis). 
Moix, P., Beccaletto, L., Masset, O., Kozur, H., Dumitrica, P., Vachard, D., Martini, R., Stampfli, G.M., 2011. Geology and correlation of the Mersin Mélanges, Southern Turkey. Turkish Journal of Earth Sciences 20, 57-98.

Moix, P., Beccaletto, L., Kozur, H., Hochard, C., Rosselet, F., Stampfli, G.M., 2008a. A new classification of the Turkish terranes and sutures and its implication for the paleotectonic history of the region. Tectonophysics 451 , 7-39.

Moix, P., Hungerbühler, A., Guex, J., Stampfli, G.M., 2008b. First evidence of Tuvalian (upper Carnian) radiolarians from the Kopría Mélange in Rhodos (Greece). 33IGC, Oslo.

Moix, P., Kozur, H.W., Stampfli, G.M., Mostler, H., 2007. New paleontological, biostratigraphic and paleogeographic results from the Triassic of the Mersin Melange, SE Turkey. In: Lucas, S.G., Spielmann, J.A. (Eds.), The Global Triassic, 41. Bulletin of the New Mexico Museum of Natural History and Science, New Mexico, pp. 282-305.

Mutti, E., Orombelli, G., Pozzi, R., 1970. Geological studies on the Dodecanes Islands (Aegean Sea) - IX. Geological map of the Island of Rhodes (Greece), scale 1:50000 - Explanatory notes. Ann. Géol. Pays Helléniques 22, $77-226$.

O’Dogherty, L., Carter, E.S., Dumitrica, P., Goričan, S., De Wever, P., Hungerbühler, A., Bandini, A.N., Takemura, A., 2009. Catalogue of Mesozoic radiolarian genera. Part 1, Triassic. Geodiversitas 31 (2), 213-270.

O’Dogherty, L., Carter, E.S., Goričan, S., Dumitrica, P., 2010. Triassic radiolarian biostratigraphy. In: Lucas, S.G. (Ed.), The Triassic Timescale. Special Publications of the Geological Society of London, pp. 163-200.

Ozsvárt, P., Moix, P., Kozur, H., 2015. New Carnian (Upper Triassic) radiolarians from the Sorgun Ophiolitic Mélange, Southern Turkey. Neues Jahrbuch für Geologie und Paläontologie Abhandlungen 277, 337-352.

Parlak, O., Delaloye, M., 1996. Geochemistry and timing of postmetamorphic dike emplacement in the Mersin ophiolite (southern Turkey): new age constraints from 40Ar-39Ar geochronology. Terra Nova 8, 585-592.
Petrushevskaya, M.G., 1981. Nassellarian radiolarians from the world oceans, Publications of the Zoological Institute, Academy of Sciences of the USSR. Description of the Fauna of the USSR. Nauka, Leningradskoe Otdelenie, Leningrad, USSR, pp. 1-405 (in Russian).

Robertson, A.H.F., 2002. Overview of the genesis and emplacement of Mesozoic ophiolites in the Eastern Mediterranean Tethyan region. Lithos 65, 1-67.

Schmid, M.S., Bernoulli, D., Fügenschuh, B., Georgiev, N., Kounov, A., Matenco, L., Oberhänsli, R., Pleuger, J., Schefer S., Schuster R., Ustaszewski K., van Hunsbergen, D. Tectonic units of the Alpine collision zone between Eastern Alps and Western Turkey, Unpublished map.

Sugiyama, K., 1997. Triassic and Lower Jurassic radiolarian biostratigraphy in the siliceous claystone and bedded chert units of the southeastern Mino Terrane, Central Japan. Bulletin of the Mizunami Fossil Museum 24, 79-193.

Tekin, U.K., 1999. Biostratigraphy and systematics of late Middle to Late Triassic radiolarians from the Taurus Mountains and Ankara region, Turkey. Geologisch Paläontologische Mitteilungen Innsbruck. Sonderband 5, 1-296.

Tekin, U.K., Bedi, Y., 2007a. Middle Carnian (Late Triassic) Nassellaria (Radiolaria) of Köseyahya Nappe from eastern Taurides, eastern Turkey. Rivista Italiana di Paleontologia e Stratigrafia 113, 167-190.

Tekin, U.K., Bedi, Y., 2007b. Ruesticyrtiidae (Radiolaria) from the middle Carnian (Late Triassic) of Koseyahya Nappe (Elbistan, eastern Turkey) Geologica carpathica 58, 153-167.

Wang, Y., Wang, J.-P., Pei, F., 2002. A Late Triassic radiolarian fauna in the Dingqing ophiolite belt, Xizang (Tibet). Acta Micropalaeontologica Sinica 19, 323-336.

Yeh, K.Y., 1989. Studies of Radiolaria from Fields Creek Formation, east-central Oregon, USA. Bulletin of the national Museum of natural Science, Taiwan 1, 43-109.

Yeh, K.Y., 1990. Taxonomic studies of Triassic Radiolaria from Busuanga Island, Philippines. Bulletin of the national Museum of natural Science, Taiwan 2, $1-63$. 